\title{
A review of the South American genera of Cimbicidae (Insecta, Hymenoptera)
}

\author{
Lars VILHELMSEN ${ }^{1, *}$, David R. SMITH ${ }^{2}$ \& Leonardo A. MALAGÓN-ALDANA ${ }^{3}$ \\ ${ }^{1,3}$ Zoological Museum, Natural History Museum of Denmark, SCIENCE, University of Copenhagen, \\ Universitetsparken 15, DK-2100, Copenhagen Ø, Denmark. \\ ${ }^{2}$ Systematic Entomology Laboratory, Agricultural Research Service, U.S. Department of Agriculture, \\ c/o National Museum of Natural History, Smithsonian Institution, P.O. Box 37012, MRC 168, \\ Washington D.C. 20013-7012, USA. \\ *Corresponding author: lbvilhelmsen@snm.ku.dk \\ 2Email: sawfly2@aol.com \\ ${ }^{3}$ Email: leonardomalagon@snm.ku.dk \\ *urn:1sid:zoobank.org:author:96FC3783-9FA7-421E-B292-6718A3762D45 \\ ${ }^{2}$ urn:lsid:zoobank.org:author:B25C3A30-9EF6-4561-8DCE-C95869DFD7E8 \\ ${ }^{3}$ urn:1sid:zoobank.org:author:4682DF93-FD43-4DDD-BC55-C323F1D2C738
}

\begin{abstract}
The South American genera of the Cimbicidae are reviewed. Five genera and nine species are recognized. Redescriptions of all genera and an identification key to all species are provided. All species are illustrated, including both sexes and aberrant specimens when relevant. The South American Cimbicidae are grouped in the subfamily Pachylostictinae, but there is substantial morphological divergence at the genus level. This and the isolated geographic and phylogenetic position relative to the other subfamilies of Cimbicidae indicates that the Pachylostictinae have evolved in isolation for a substantial amount of time. Host plant records are known for only one species, Pseudopachylosticta subflavata, which is mainly found in the Chacoan subregion. The distribution of the remaining species falls almost exclusively within the range of the Parana subregion forest provinces, a biome that has been much reduced by human activity in the past half millennium. It is likely that these rarely collected wasps are threatened by habitat degradation.
\end{abstract}

Keywords. 'Symphyta', Tenthredinoidea, neotropics, identification, distribution.

Vilhelmsen L., Smith D. R. \& Malagón-Aldana L. A. 2018. A review of the South American genera of Cimbicidae (Insecta, Hymenoptera). European Journal of Taxonomy 482: 1-36. https://doi.org/10.5852/ejt.2018.482

\section{Introduction}

The Cimbicidae is one of the smaller families of true sawflies (Tenthredinoidea), comprising some 200 species worldwide (Taeger et al. 2010; Vilhelmsen 2018). The majority of its members are distributed in the Holarctic and Oriental regions; members of the subfamilies Abiinae and Cimbicinae occur widely in these areas, with the majority of the diversity in eastern Asia; the subfamily Corynidinae is restricted to 
the Palaearctic (Vilhelmsen 2018). In contrast, the fourth subfamily of Cimbicidae, the Pachylostictinae, occurs only in a limited part of the Neotropical Region (including areas in Argentina, Bolivia, Brazil and Paraguay), having no range overlap with the other three subfamilies (Smith 1988).

Benson (1938) produced the currently accepted subfamily classification scheme for Cimbicidae. This scheme was recently tested in a phylogenetic context by Vilhelmsen (2018) and largely confirmed. In contrast to the other subfamilies recognized by Benson (see above), the monophyly of the Pachylostictinae was not always corroborated, but putative autapomorphies were identified (see Discussion). Despite having the lowest species diversity among the cimbicid subfamilies, the Pachylostictinae are morphologically diverse at the genus level, indicating that they have evolved in isolation for a long time.

All original descriptions of South American genera of Cimbicidae are in German, in some cases with a diagnosis in Latin (the description of Enslinia Jörgensen, 1913 (= Pseudabia Schrottky, 1910) is in Spanish); they are mostly scattered in obscure and difficult to access publications. Prior to the present study, the only published habitus images (all in dorsal view, with wings extended) of pachylostictines are the color illustrations in Perty (1830: plate XXVI.2) of the male of Pachylosticta chalybea, 1833 (= Pachylosticta violacea Klug, 1824), in Klug (1834: plate II.5) of the female of Plagiocera thoracica, 1834 (= Pachylosticta albiventris Klug, 1824), and in Kirby (1882: plate I.9) of Amasis subflavata, 1882 (= Pseudopachylosticta subflavata [Kirby, 1882]); none of these display much detail. Otherwise, the original descriptions depict at most some of the anatomical details essential for diagnosis and identification, e.g., the $1^{\text {st }}$ valvula; this is also the case with Smith (1988: figs 28-52).

Smith (1988) presented the most recent review of Pachylostictinae, recognizing nine species in five genera: five species in the nominal genus Pachylosticta Klug, 1824, the monotypical Brasilabia Conde, 1937, Lopesiana Smith, 1988, Pseudabia Schrottky, 1910, and Pseudopachylosticta Mallach, 1929. Smith's review of the existing material was very comprehensive, and he also included an identification key. The specimen records he provided have been incorporated and expanded by us. Smith (1988) synonymized a number of taxa in Pseudopachylosticta; no taxonomic changes are suggested here, Smith (1988) has been taken as the base line.

The only published host information for Pachylostictinae is for Pseudopachylosticta subflavata. Paterson et al. (2014) reared the species from Pereskia aculeata (Cactaceae) and Talinum paniculatum (Talinaceae) collected in Santa Catarina and Paraná Provinces, Brazil, respectively. The rearing was part of a survey of natural enemies of $P$. aculeata which is considered an invasive species in South Africa; the native range of the plant is in the Neotropics. P. subflavata was deemed unsuitable for biological control because it might attack Talinum spp. native to South Africa (Paterson et al. 2014). No descriptions of any larvae of Pachylostictinae have been published.

The present paper provides the first comprehensive overview of the Pachylostictinae, with detailed redescriptions of all genera in English, as well as habitus images and a revised identification key covering all recognized species; this represents a substantial improvement in the accessibility of knowledge of these somewhat overlooked wasps. Furthermore, we explore the current distribution of the South American Cimbicidae, its possible causes and the potential conservational consequences.

\section{Material and methods}

\section{Examination and imaging of specimens}

Many records listed in this paper were originally acquired by Smith (1988) and have not been rechecked. Specimens were examined with a Leica M205C dissection microscope. Digital images were produced 
with a Visionary Digital imaging setup with flash lightning and P-51 Camlift Driver ver. 2.6.1 to control the camera. A cylinder of semitransparent plastic and a cone of semitransparent paper were placed around the specimen to disperse the light. Images were stored in Adobe Lightroom 2 and composite images were compiled from stacks with the software Zerene Stacker ver. 1.04 by implementing the Pyramidal Stacking Method (PMax).

\section{Institutional abbreviations}

Abbreviations according to Evenhuis (2007).

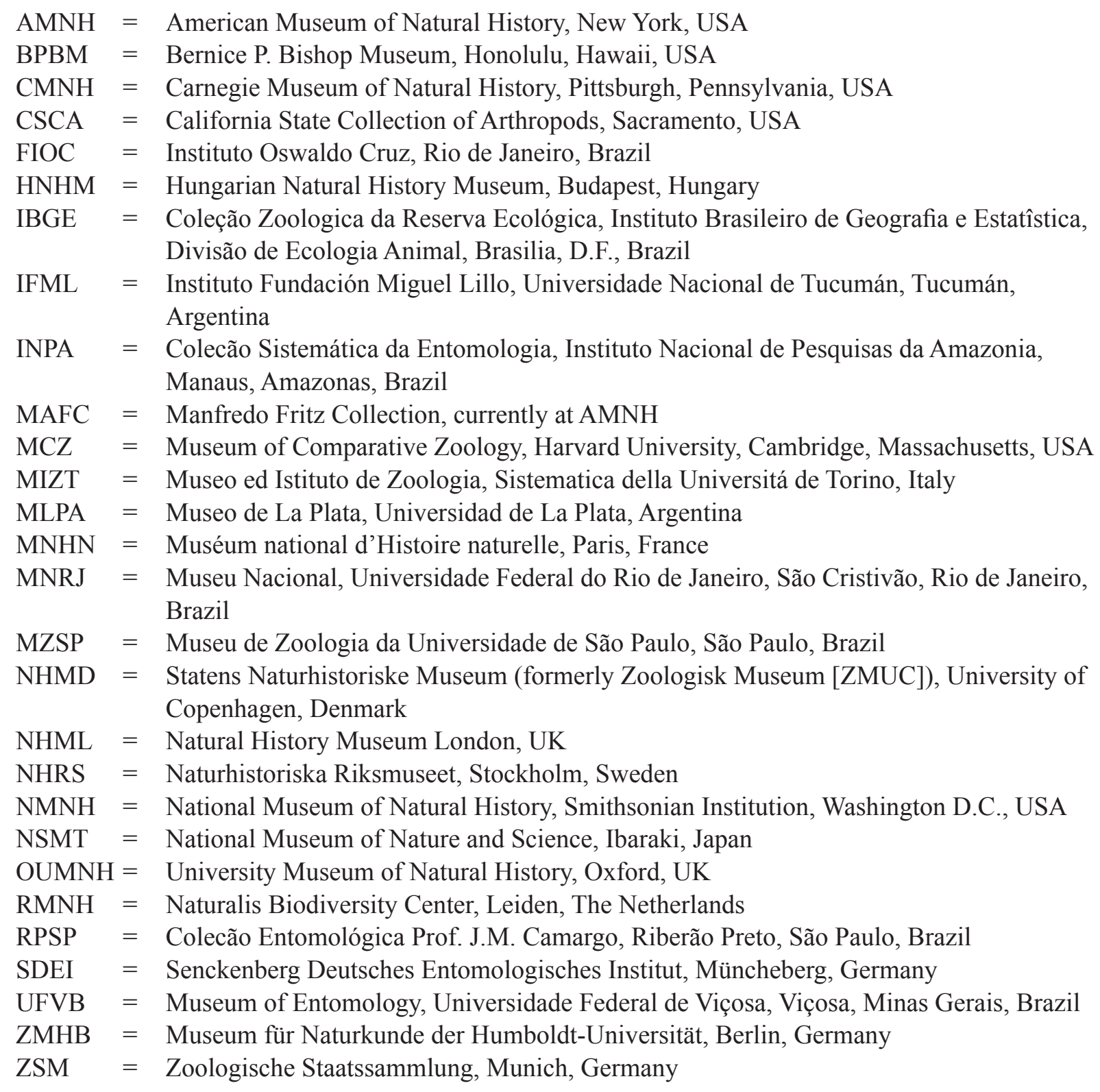

The map included in Fig. 16 was modified from:

https://upload.wikimedia.org/wikipedia/commons/5/51/South_America_laea_relief_location_map.jpg

In the redescriptions, the terminology for the ovipositor apparatus follows Vilhelmsen (2000). 


\section{Results}

Order Hymenoptera Linné, 1758

Family Cimbicidae W. Kirby, 1837

Subfamily Pachylostictinae Benson, 1938

\section{Key to the species of South American Cimbicidae}

1. Antennae with at least five antennomeres, one or more apical antennomeres expanded, forming distinct club (Fig. 1A-B); mesopseudosternal sulcus lateroventrally on mesopleuron absent; fore wing vein $2 \mathrm{r}$ always present, vein Rs always absent between cells $1 \mathrm{R}$ and Rs (Fig. 2A-B); lateral part of abdominal terga separated from median by fold or unsclerotized line, spiracles below line on lateral part (Fig. 3A)

2. Cimbicidae

- Antennae with various numbers of antennomeres, sometimes less than five; apical antennomeres usually not expanded; mesopseudosternal sulcus lateroventrally on mesopleuron present or absent; fore wing $2 \mathrm{r}$ absent or present, vein Rs absent or present (Fig. 2C) between cells 1R and Rs; if antennal club present, then fore wing vein $2 \mathrm{r}$ absent (Fig. 2C); lateral part of abdominal terga rarely separated from median part (Fig. 3B) not Cimbicidae

2. Five antennomeres present (Fig. 1A); median mesoscutal sulcus and notauli always well developed (Fig. 4A); fore wing with vein $\mathrm{M}$ always joins $\mathrm{Sc}+\mathrm{R}$ close to Rs $+\mathrm{M}$ junction (Fig. 2A). Exclusively South American .................................................. South American Cimbicidae

- Five or more antennomeres present (Fig. 1B); median mesoscutal sulcus and notauli present or absent (Fig. 4B); if present, then fore wing vein $\mathrm{M}$ joins $\mathrm{Sc}+\mathrm{R}$ well separate from Rs $+\mathrm{M}$ junction (Fig. 2B). Holarctic or Oriental, never South American other Cimbicidae

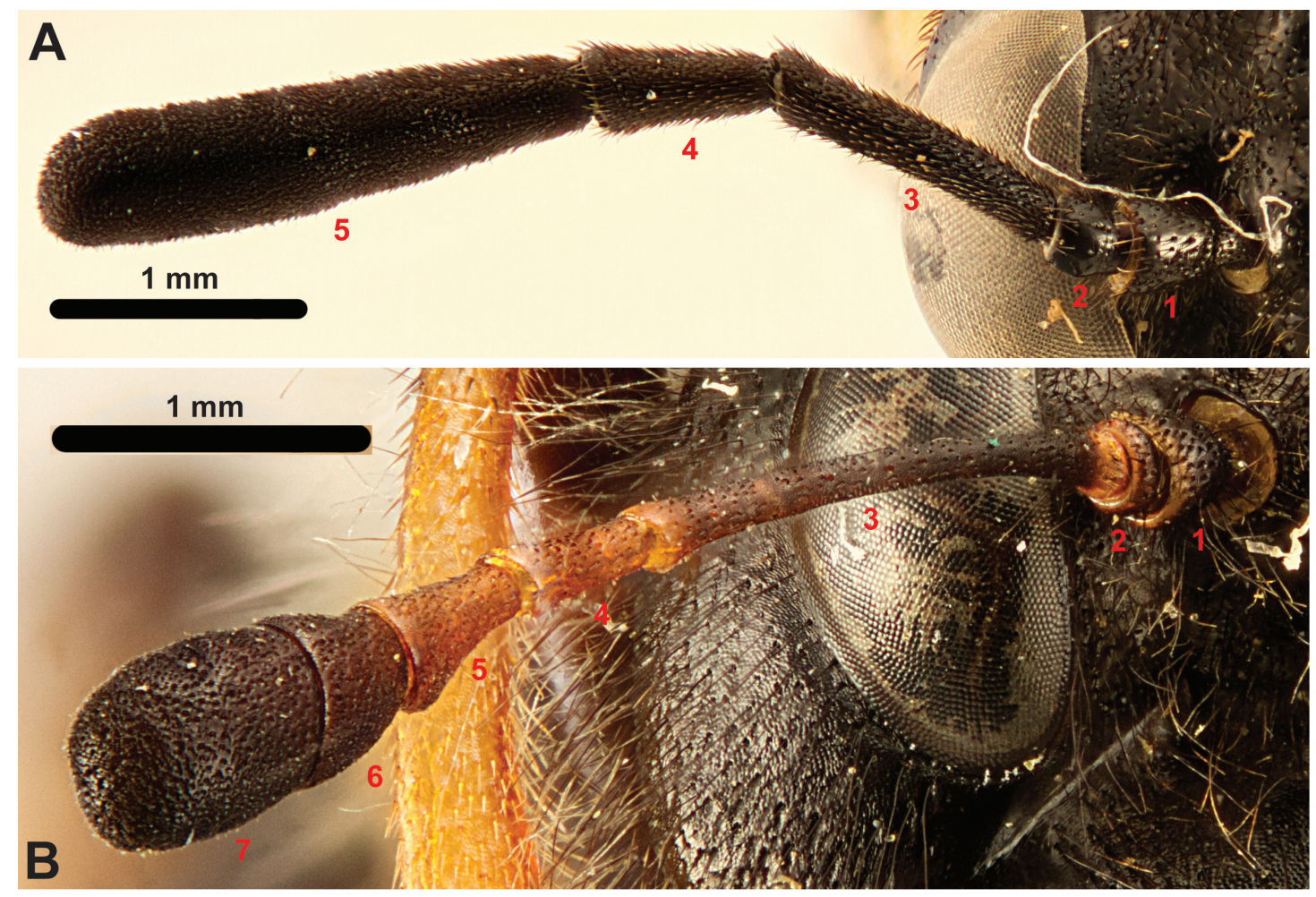

Fig. 1. Antenna. A. Pseudabia fusca Schrottky, 1910, q (NMNH). B. Trichiosoma latreillei (Leach, 1817), ㅇ (NHML). 

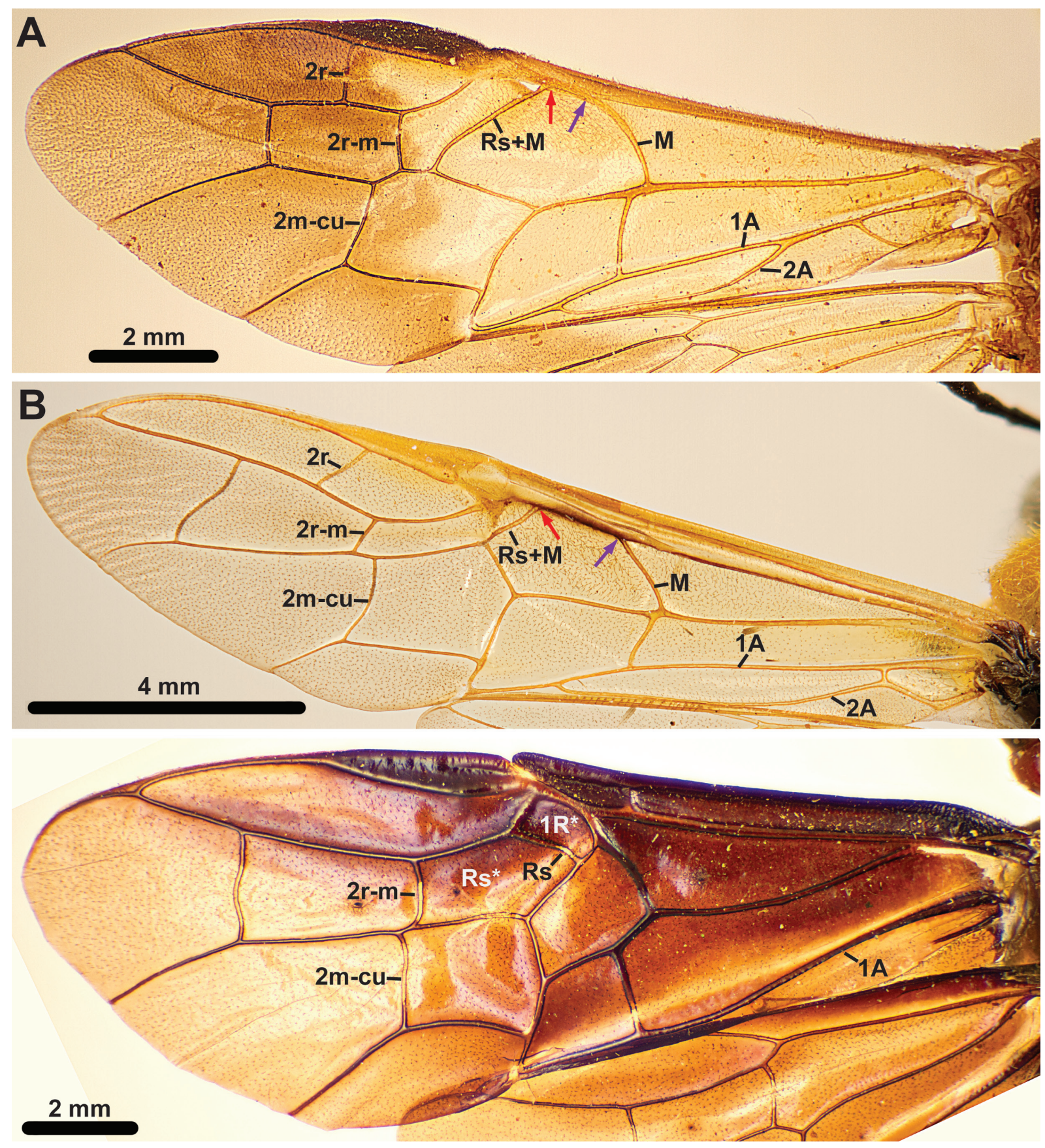

Fig. 2. Fore wing, 우. A. Pachylosticta apicalis (Westwood, 1835) (NHRS). B. Agenocimbex maculata (Marlatt, 1898) (NSMT). C. Pergidae, Parasyzygoniinae: Parasyzygonia cyanoptera (Klug, 1824) (NHMD). Abbreviations: Rs, Rs+M, M, 2r, 2r-m, 2m-cu, 1a, 2a = wing veins; 1R*, Rs* = wing cells; violet arrow $=$ junction between veins $\mathrm{Sc}+\mathrm{R}$ and $\mathrm{M}$; red arrow $=$ junction between veins $\mathrm{Sc}+\mathrm{R}$ and Rs+M. 

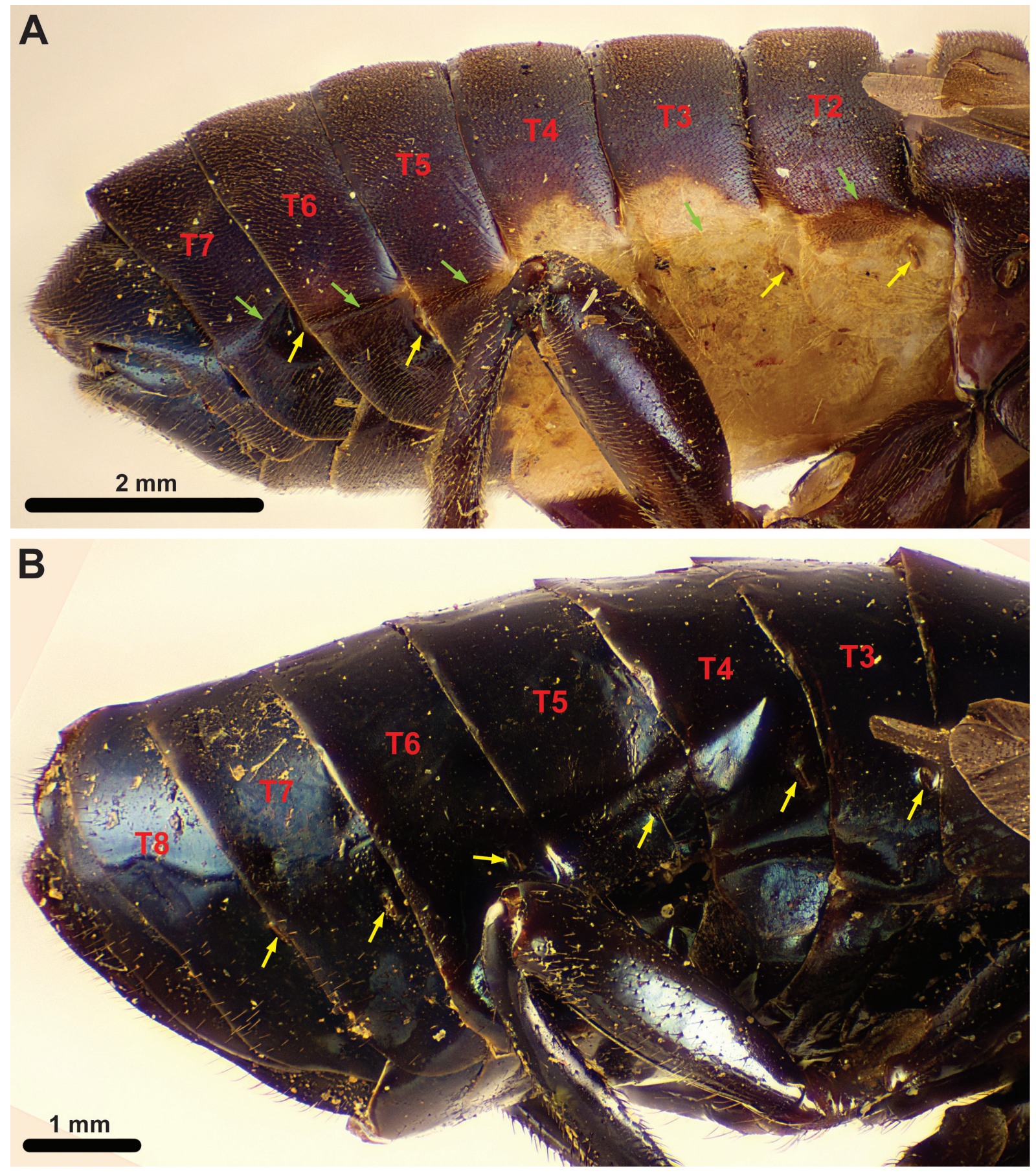

Fig. 3. Abdomen, lateral. A. Pachylosticta albiventris Klug, 1824, § (NHMD). B. Pergidae, Parasyzygoniinae: Parasyzygonia cyanoptera (Klug, 1824), o (NHMD). Abbreviations: T[n] = abdominal terga $[\mathrm{n}]$. yellow arrow $=$ spiracle; green arrow $=$ separation between median and lateral parts of abdominal terga. 


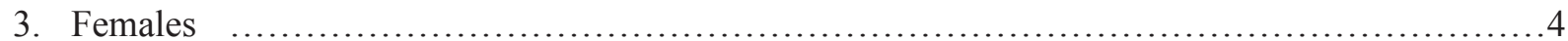

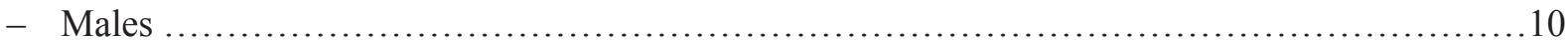

4. Thorax extensively reddish brown, sometimes with mesoscutum blue-black metallic (Figs 8, 10-11, 14A)

- Thorax predominantly dark brown to black (Figs 5A, 6A, 13A), pronotal corners may be creamy white; never extensively reddish brown .....

5. Hind basitarsomere shorter than tarsomeres 2-4 combined (Fig. 14A); fore wing vein $1 \mathrm{~m}$-cu inserts on vein Rs $+\mathrm{M}$ more proximally, distance between $2 \mathrm{r}-\mathrm{m}$ and $1 \mathrm{~m}-\mathrm{cu}$ insertions on Rs $+\mathrm{M}$ (red on Fig. 14D) at least $1 / 3$ of distance between $\mathrm{M}$ and $1 \mathrm{~m}$-cu insertions on Rs+M (green on Fig. 14D); hind wing cell Rs much smaller than cell M, cell M extending to vein Rs proximally (Fig. 14D)

Pseudopachylosticta subflavata Kirby, 1882

- Hind basitarsomere longer than tarsomeres 2-4 combined (cf. Fig. 9A); fore wing vein 1m$\mathrm{cu}$ inserts on vein Rs $+\mathrm{M}$ distally, distance between $2 \mathrm{r}-\mathrm{m}$ and $1 \mathrm{~m}-\mathrm{cu}$ insertions on Rs $+\mathrm{M}$ (red on Fig. 8A) at most $1 / 4$ of distance between $\mathrm{M}$ and $1 \mathrm{~m}$-cu insertions on Rs+M (green on Fig. 8A); hind wing cells Rs and $\mathrm{M}$ of approx. equal size, cell $\mathrm{M}$ does not reach vein Rs (Fig. 10A; see also Fig. 9B) 6. Pachylosticta (females)

6. Abdomen colored blue-black metallic throughout (Fig. 8A) ...Pachylosticta albiventris Klug, 1824

- Abdominal segments 1-3/5 reddish brown, remaining segments blue-black metallic (Figs 10A, 11A)

7. Apical antennomere with elongate, lighter colored area on ventral side (Fig. 10B-C); mesoscutum and mesoscutellum reddish brown (Fig. 10A); apex of fore wing darkly infuscate, proximal part much lighter (Fig. 10A) (male unknown) .........Pachylosticta apicalis (Westwood, 1835)

- Apical antennomere without elongate, lighter colored area on ventral side (Fig. 11B); mesoscutum mostly blue-black metallic, mesoscutellum reddish brown (Fig. 11A) (male unknown) Pachylosticta plaumanni Malaise, 1939
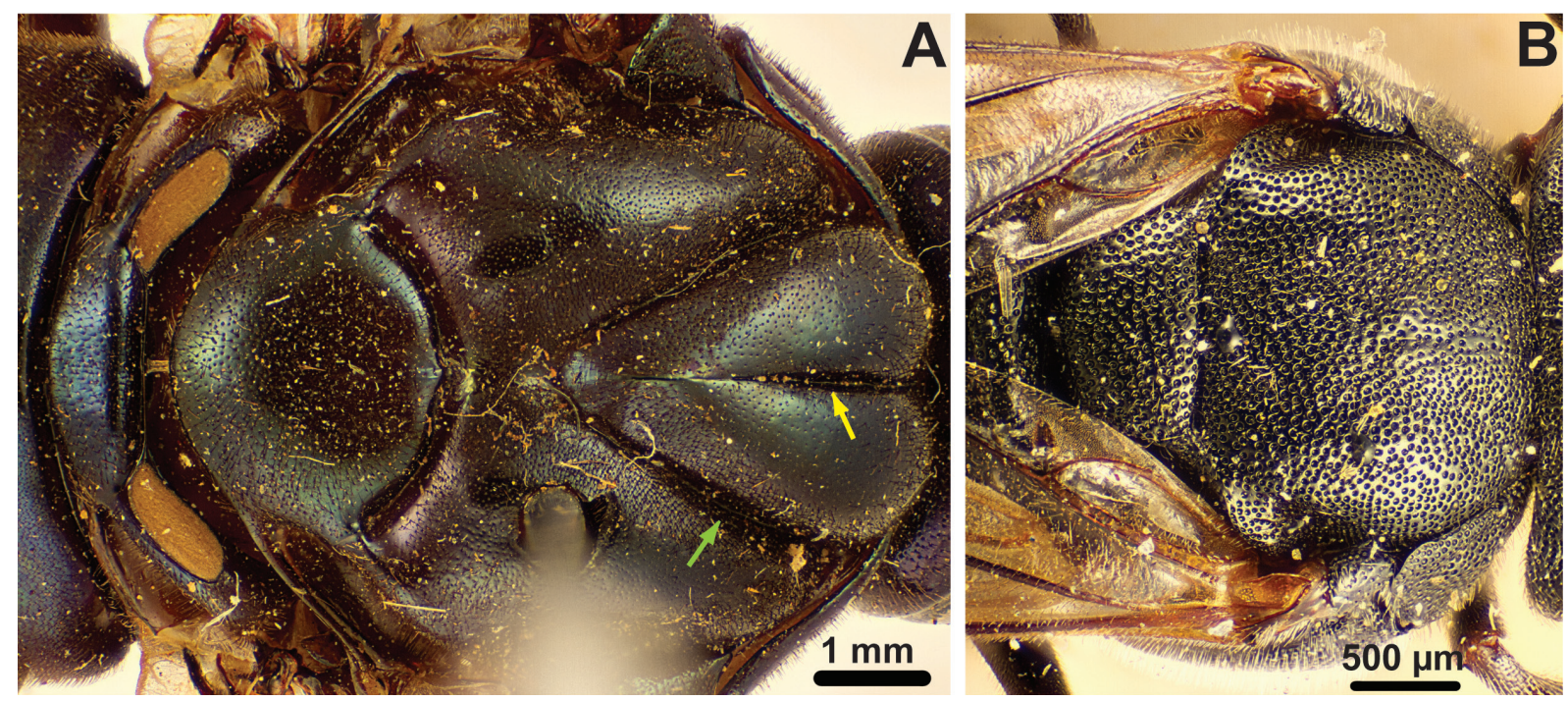

Fig. 4. Thorax, dorsal. A. Pachylosticta albiventris Klug, 1824, §ิ (NHMD). B. Corynis obscura (Fabricius, 1775), o (NHMD). Abbreviations: yellow arrow $=$ median mesoscutal sulcus; green arrow $=$ notaulus. 
8. Clypeus predominantly creamy white, contrasting with blackish-brown color of the rest of the head capsule (Fig. 5B); $1^{\text {st }}$ abdominal tergum subdivided medially by narrow longitudinal line (Fig. 5C) (male unknown) ...............................Brasilabia clypealba (Conde, 1932)

- Clypeus blackish brown like the rest of the head capsule (Figs 6B, 13B); $1^{\text {st }}$ abdominal tergum continuous medially (Figs 6C, 13A) .......................................................

9. Dorsomedian margin of torulus pale, overhanging antennal foramen (Fig. 6B); dorsolateral corners of pronotum dark brown to black, as rest of pronotum (Fig. 6C); hind basitarsomere longer than tarsomeres 2-4 combined; hind wing vein M complete, cells Rs and M separated (Fig. 6A; see also Fig. 9B); body length less than $1 \mathrm{~cm}$......Lopesiana thomasi (Conde, 1937)

- Dorsomedian part of torulus dark, not overhanging antennal foramen (Fig. 13B); dorsolateral corners of pronotum creamy white, contrasting with darker color of the rest of pronotum (Fig. 13C); hind basitarsomere shorter than tarsomeres 2-4 combined; hind wing vein $\mathrm{M}$ discontinuous, cells Rs and M partly confluent (Fig. 13A [insert]); body length at least $1.5 \mathrm{~cm}$ (male unknown) ....

Pseudabia fusca Schrottky, 1910

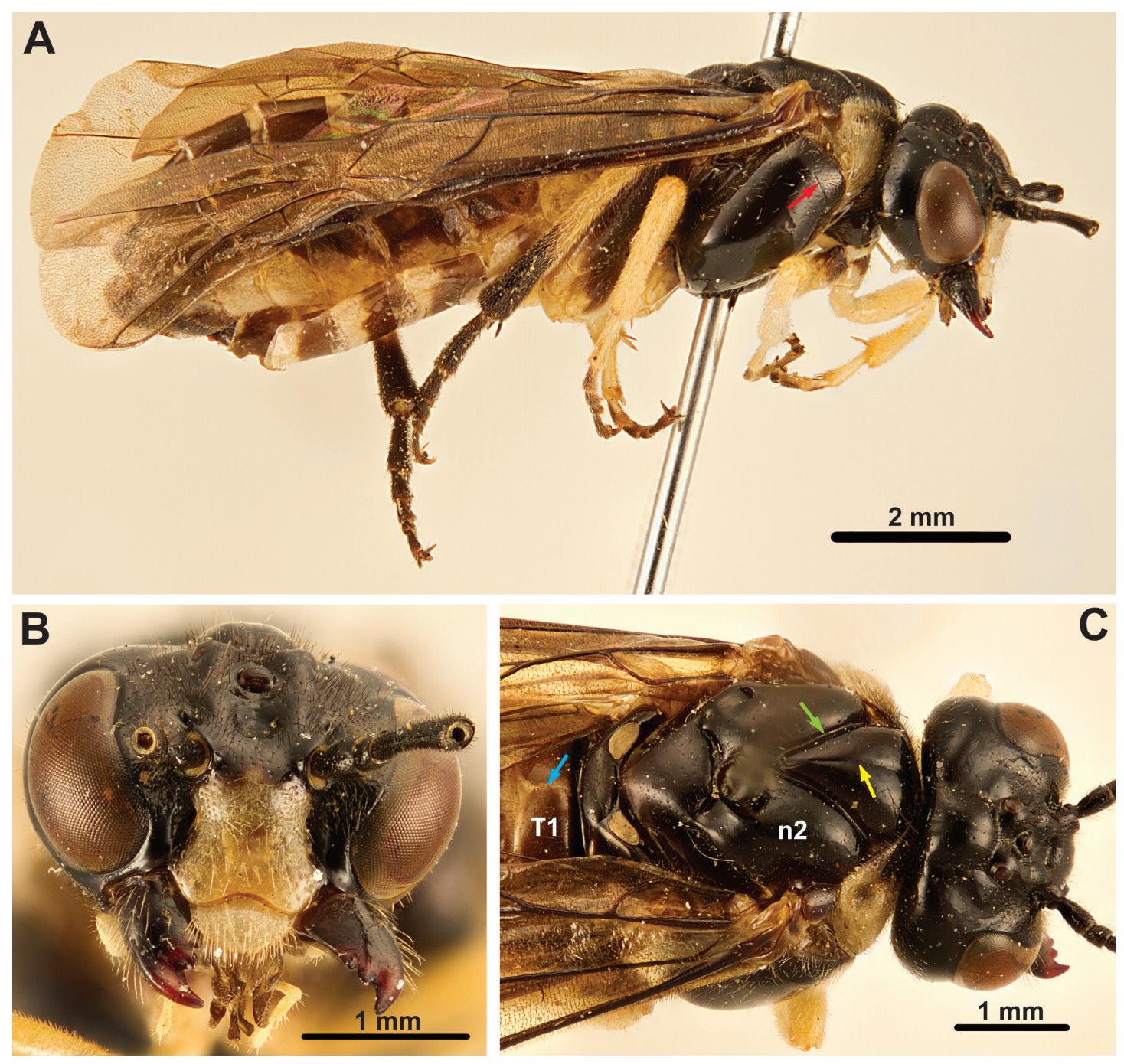

Fig. 5. Brasilabia clypealba (Conde, 1932), q (NMNH). A. Habitus, lateral. B. Head anterior. C. Thorax, dorsal. Abbreviations: $\mathrm{n} 2=$ mesoscutum; $\mathrm{T} 1=1^{\text {st }}$ abdominal tergum; red arrow $=$ mesopleural groove; blue arrow $=$ membranous line on $\mathrm{T} 1$; yellow arrow $=$ median mesoscutal sulcus; green arrow $=$ notaulus . 

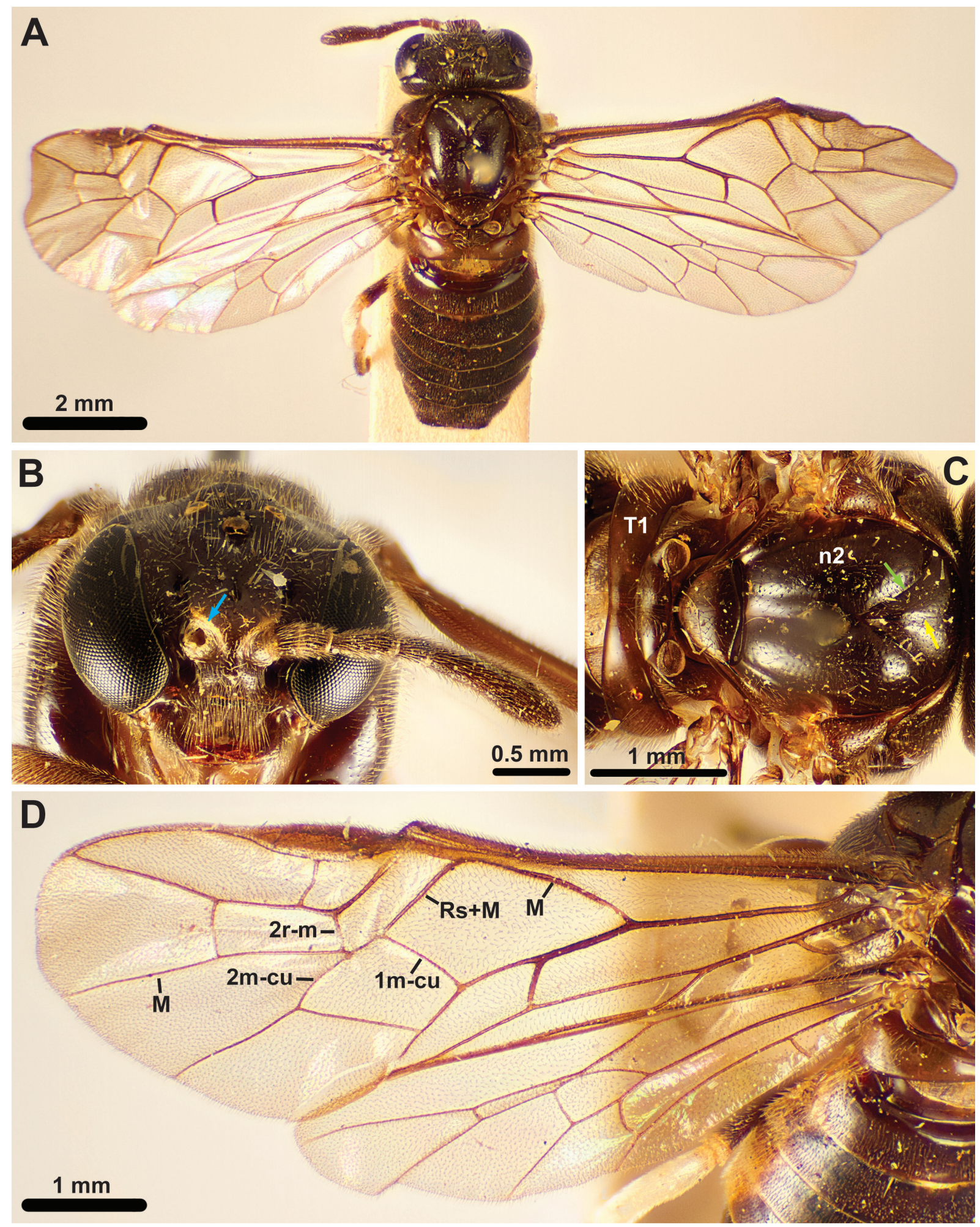

Fig. 6. Lopesiana thomasi (Conde, 1937), $q$ (FIOC). A. Habitus, dorsal. B. Head anterior. C. Thorax, dorsal. D. Wings. Abbreviations: M, Rs $+\mathrm{M}, 1 \mathrm{~m}-\mathrm{cu}, 2 \mathrm{~m}-\mathrm{cu}, 2 \mathrm{r}-\mathrm{m}$ = wing veins; $\mathrm{n} 2$ = mesoscutum; $\mathrm{T} 1=$ $1^{\text {st }}$ abdominal tergum; blue arrow $=$ dorsomedian margin of torulus; yellow arrow $=$ median mesoscutal sulcus; green arrow $=$ notaulus . 
10. Antennae inserted very low on face, distance between toruli and median ocellus almost twice the distance between toruli and ventral margin of clypeus (Fig. 7C); body predominantly dark brown to black, no metallic areas (Fig. 7A); body length well below $1 \mathrm{~cm}$...Lopesiana thomasi (Conde, 1937)

- Antennae inserted slightly below middle of face, distance between toruli and median ocellus at most equal to distance between toruli and ventral margin of clypeus (Figs 8B, 10B, 11B, 14B); body with extensive blue-black metallic coloration (Figs 9A, 12); body length approx. $1.5 \mathrm{~cm} \ldots \ldots \ldots \ldots . .11$

11. Hind basitarsomere shorter than tarsomeres 2-4 combined (cf. Fig. 14A); fore wing pterostigma not thickened and protruding from rest of anterior wing margin (Fig. 15); hind wing cell Rs much smaller than cell M, cell M extending to vein Rs proximally (Fig. 15) ....

Pseudopachylosticta subflavata (Kirby, 1882)

- Hind basitarsomere longer than tarsomeres 2-4 combined (Figs 9A, 12); fore wing pterostigma thickened and protruding from rest of anterior wing margin (Figs 9B, 12); hind wing cells Rs and $\mathrm{M}$ of approx. equal size, cell M does not reach vein Rs (Fig. 9B) ...........12. Pachylosticta (males)
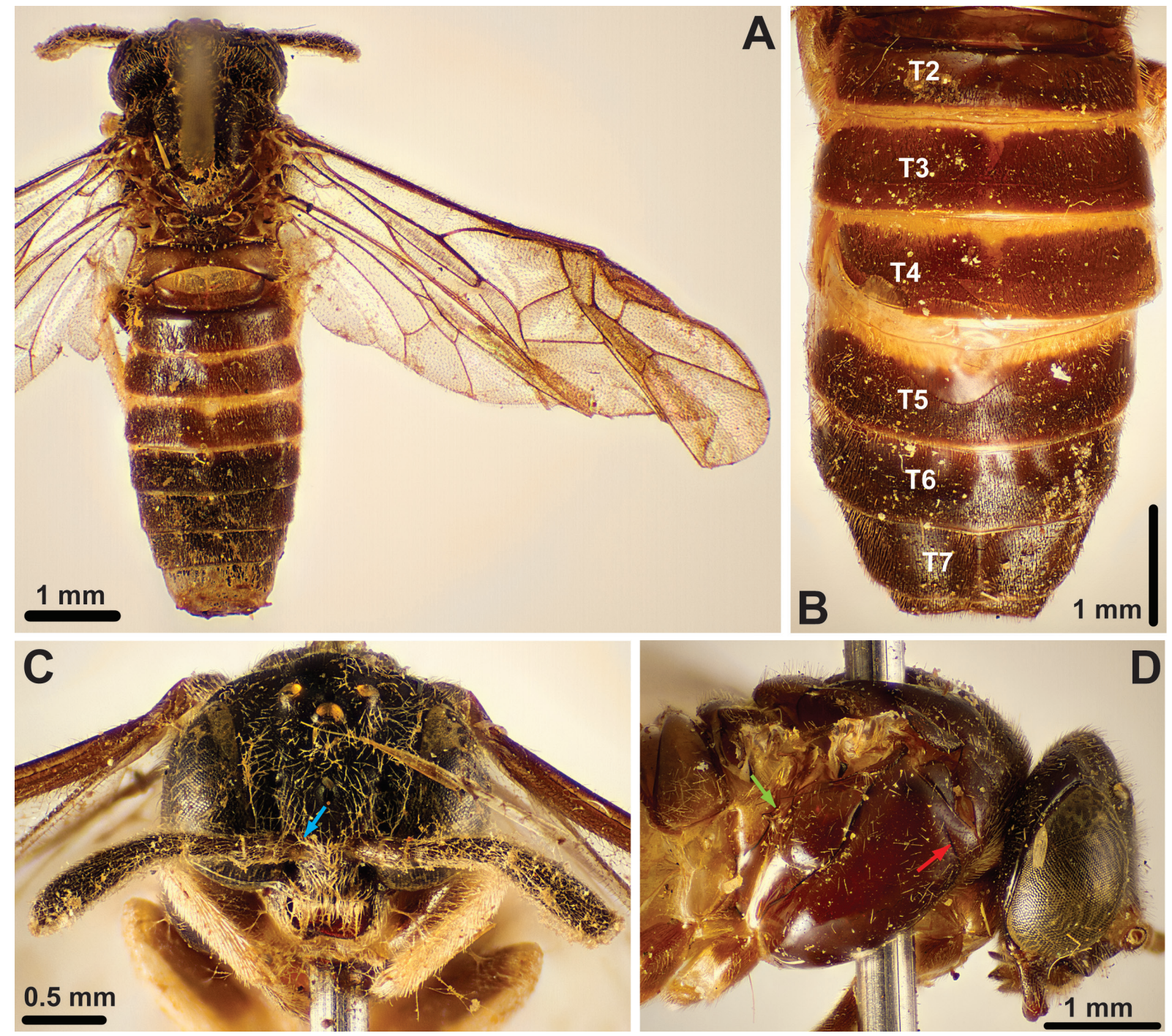

Fig. 7. Lopesiana thomasi (Conde, 1937). A, C. $\widehat{~}$. (FIOC) B, D. $q$ (FIOC). A. Habitus, dorsal. B. Abdomen, dorsal. C. Head, anterior. D. Head and thorax, lateral. Abbreviations: $\mathrm{T}[\mathrm{n}]=$ abdominal tergum $[\mathrm{n}]$; blue arrow $=$ dorsomedian margin of torulus; green arrow $=$ position of posterior thoracic spiracle; red arrow $=$ mesopleural groove. 
12. Abdominal segments $1-3$ and 7-9 in dorsal view blue-black metallic, segments $4-6$ reddish brown (Fig. 12C)

- Abdomen blue-black metallic throughout in dorsal view (Fig. 12A-B) .13

13. Abdomen with sternum and laterotergum 2-4/5 creamy white to orange, contrasting with blueblack metallic color of rest of abdomen (Fig. 9A) .............Pachylosticta albiventris Klug, 1824

- Abdomen blue-black metallic throughout (Fig. 12)

14. Posterodorsal parts of mesopleuron yellowish white, remainder of mesopleuron blue-black metallic; all legs with tibia and most of tarsus yellowish white (Fig. 12A) (female unknown)

Pachylosticta tibialis Klug, 1824

- Mesopleuron blue-black metallic throughout; legs blue-black metallic to dark brown throughout (Fig. 12C) (female unknown)

.Pachylosticta violacea Klug, 1824

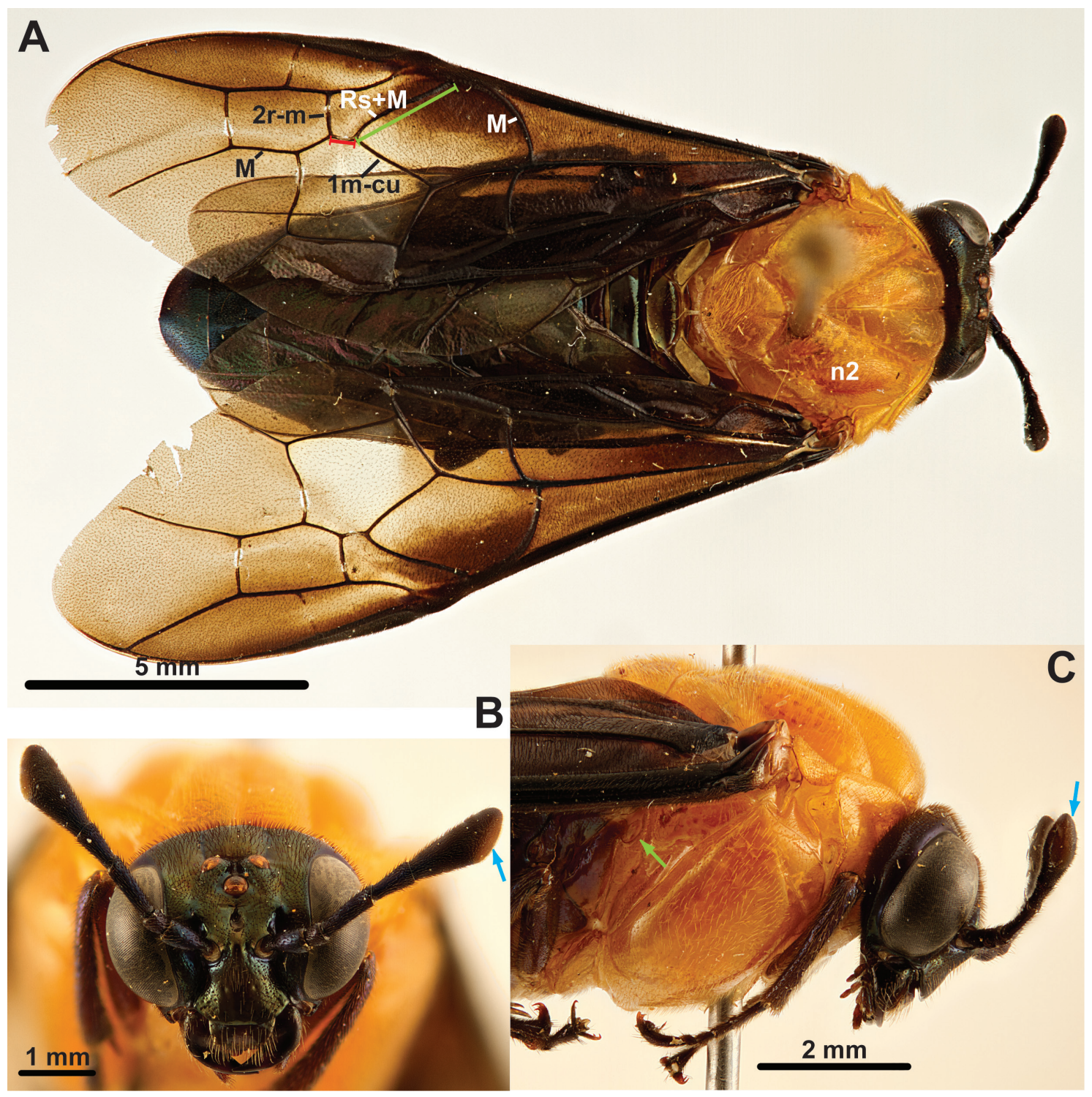

Fig. 8. Pachylosticta albiventris Klug, 1824, + (NMNH). A. Habitus, dorsal. B. Head anterior. C. Thorax, lateral. Abbreviations: $\mathrm{n} 2=$ mesoscutum; $\mathrm{M}, \mathrm{Rs}+\mathrm{M}, 2 \mathrm{r}-\mathrm{m}, 1 \mathrm{~m}-\mathrm{cu}=$ wing veins; blue arrow $=$ lighter colored area on apical antennomere; green arrow $=$ posterior thoracic spiracle. 


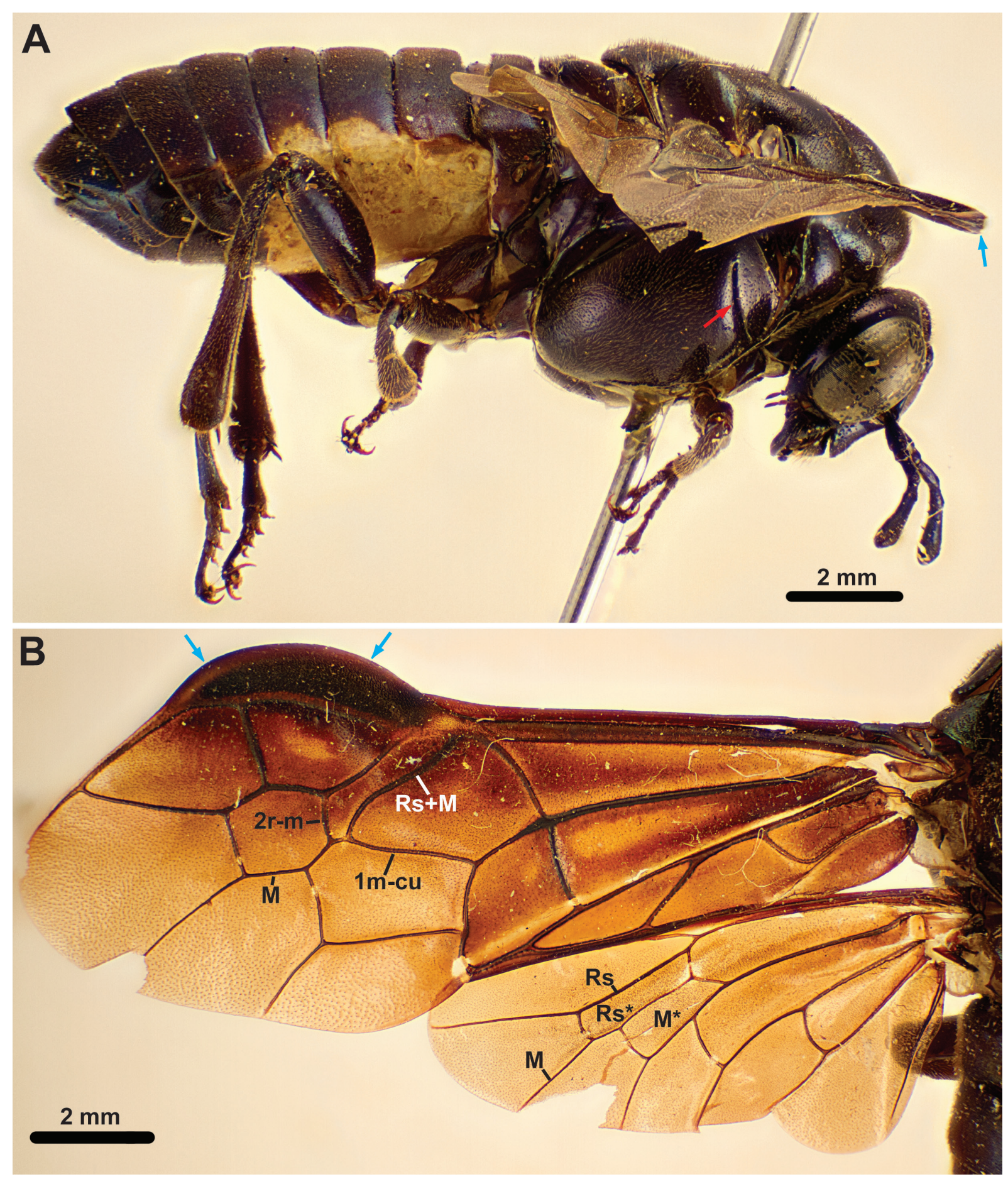

Fig. 9. Pachylosticta albiventris Klug, 1824, ठ (NHMD). A. Habitus, lateral. B. Wings. Abbreviations: $\mathrm{M}, 2 \mathrm{r}-\mathrm{m}, 1 \mathrm{~m}-\mathrm{cu}, \mathrm{Rs}, \mathrm{Rs}+\mathrm{M}=$ wing veins; $\mathrm{M}^{*}$, Rs* = wing cells; blue arrow = pterostigma; red arrow = mesopleural groove. 
Brasilabia Conde, 1937

Brasilabia clypealba (Conde, 1932)

Fig. 5

\section{Material examined}

\section{Holotype}

BRAZIL: + , São Paulo, Ypiranga, Jan. 1906, Luederwaldt leg. (MZSP).

\section{Other material}

BRAZIL: - Minas Gerais: 1 q, Viçosa, Universidad Federal de Viçosa, Areo do Deparatmento de Apicultura, $651 \mathrm{~m}$ a.s.1., $20^{\circ} 45^{\prime} \mathrm{S}, 42^{\circ} 57^{\prime} \mathrm{W}, 4$ Nov. 2007, A.I.A Pereira leg. (UFVB); 1 q same collecting data as preceding but 15 Nov. 2007 (UFVB); 1 q same collecting data as preceding but 20 Nov. 2007

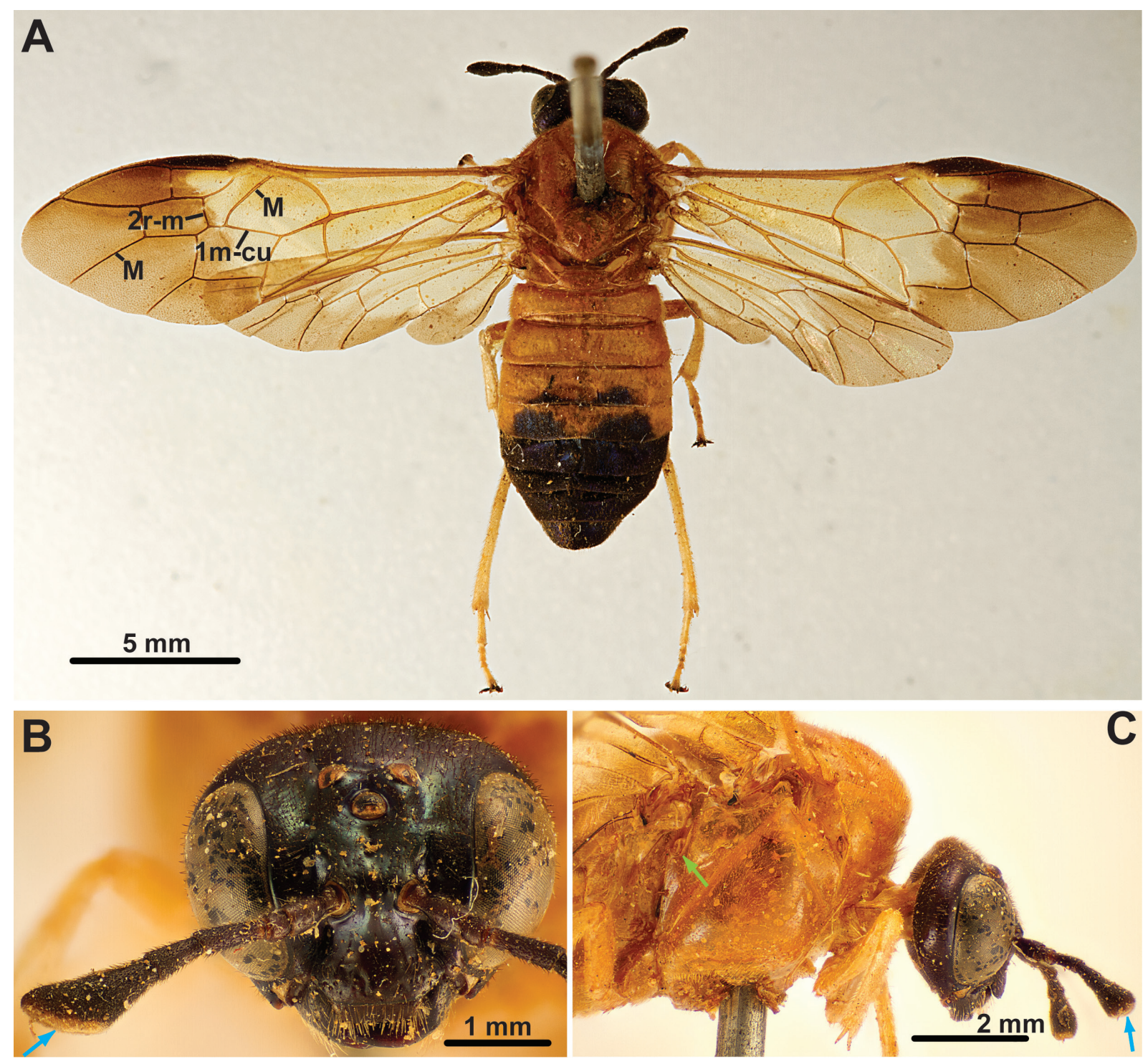

Fig. 10. Pachylosticta apicalis (Westwood, 1835), q (NHRM). A. Habitus, dorsal. B. Head anterior. C. Thorax, lateral. Abbreviations: M, 2r-m, 1m-cu = wing veins; blue arrow $=$ lighter colored area on apical antennomere; green arrow $=$ posterior thoracic spiracle. 
(UFVB). - Rio de Janeiro: 1 +, Nova Friburgo, Mury, 1-31 Jan. 1965, Gred and Guimaraes leg. (NMNH). - São Paulo: 1 , São Paulo, Cidade de Universidade, 15 Oct. 1971, C.G. Froehlic leg. (MZSP).

Redescription (female, male unknown)

MeAsurements. Medium-sized sawfly, body length $10.5 \mathrm{~mm}$.

CoLOR. Coloration predominantly black to dark brown (Fig. 5), creamy white markings of various size on all body parts (e.g., clypeus on head (Fig. 5B), lateral parts of pronotum). Legs creamy white proximally, black to dark brown distally. Wings predominantly hyaline.

HEAD. Eyes converging ventrally, inner margins slightly incurved (Fig. 5B). Posterior ocelli at level with dorsal margin of eyes. Toruli in middle of face, slightly closer to median ocellus than to ventral margin of clypeus. Epistomal sulcus absent. Clypeus with shallow incurvation medially. Gena medially less wide than width of eye, wider dorsally than ventrally. Malar space very low (Fig. 5B). Occipital carina absent. Sclerotisation between occipital and oral foramina present. Antennae with five antennomeres [from Smith 1988: fig. 34; specimen examined missing antennomeres 3-5 and 4-5, respectively]; antennomere 1 approx. $2 \times$ as long as wide, antennomere 2 approx. as wide as long, antennomere 3 approx. $2 \times$ as long as antennomere 4 [from Smith 1988], antennomere 5 slightly expanded distally

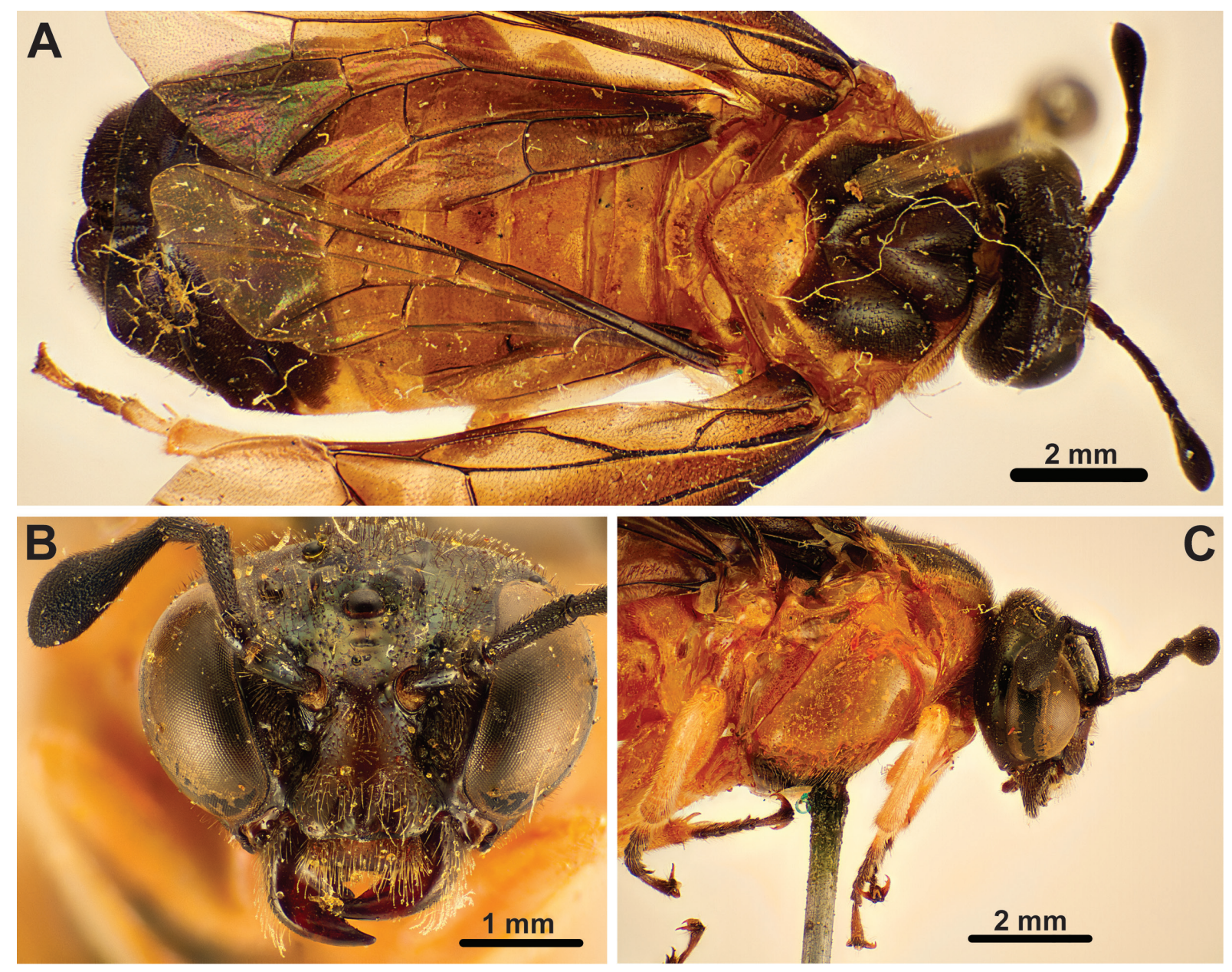

Fig. 11. Pachylosticta plaumanni Malaise, 1938, ㅇ (NHRM) A. Habitus, dorsal. B. Head anterior. C. Thorax, lateral. 

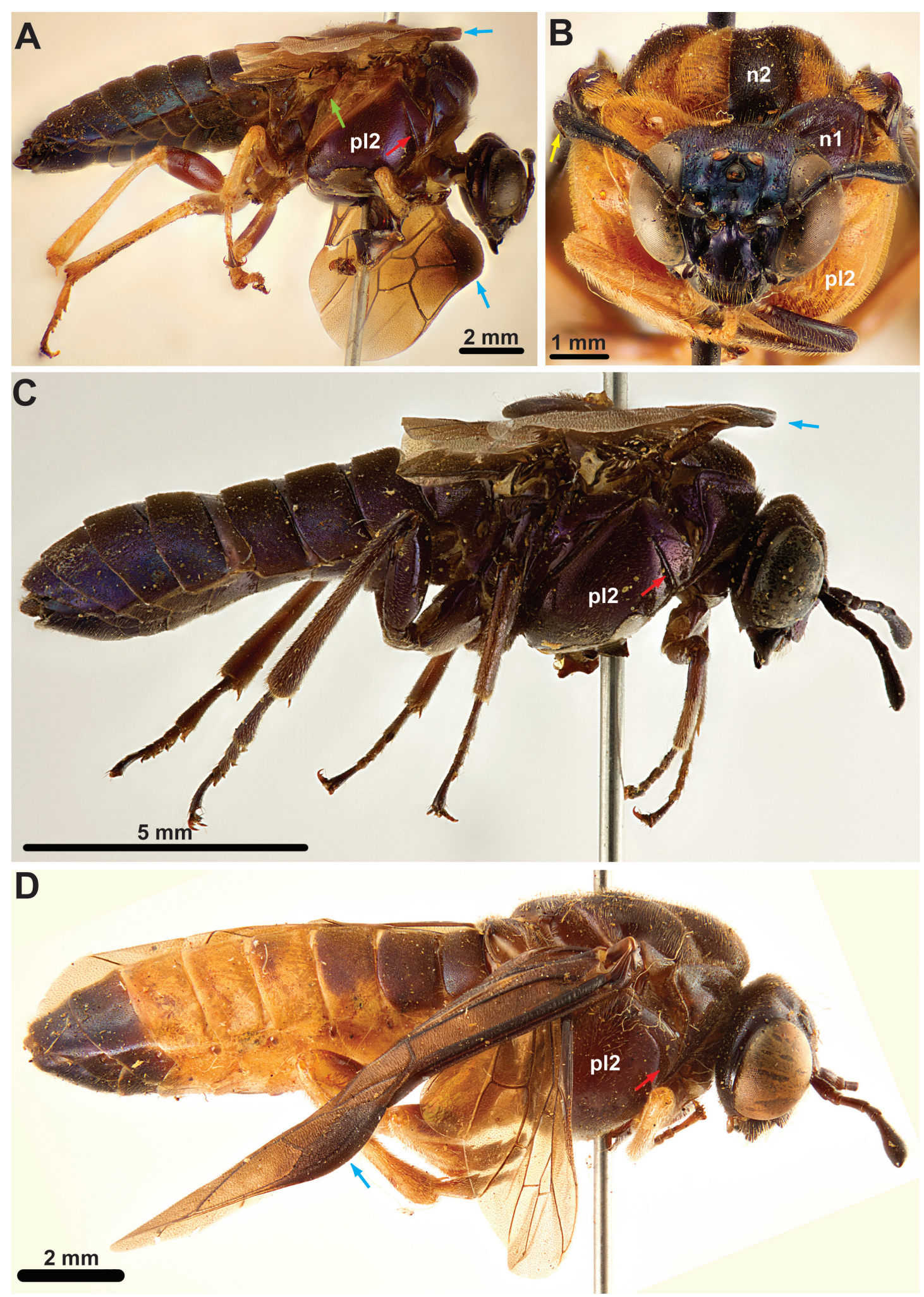

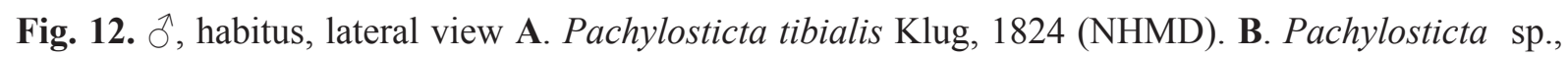
anterior view (MNHN). C. Pachylosticta violacea Klug, 1824 (NHMD). D. Pachylosticta sp. (MNRJ). Abbreviations: $\mathrm{n} 1$ = pronotum; $\mathrm{n} 2=$ mesonotum; $\mathrm{p} 12$ = mesopleuron; blue arrow = pterostigma; red arrow $=$ mesopleural groove; green arrow $=$ posterior thoracic spiracle; yellow arrow $=$ lighter colored area on apical antennomere. 
[from Smith 1988]. Labrum broad, convex, flat, hairy, distal margin evenly curved. Mandibles less than $1 / 2$ the height of head, with three teeth each (Fig. 5B), inner margin not serrated. Maxilla with stipes of approx. equal width throughout, palps with six palpomeres, longer than labial palps. Labial palps with four palpomeres, palps inserting at level with maxillary palps. Postmentum narrow, at least $3 \times$ as long as wide.

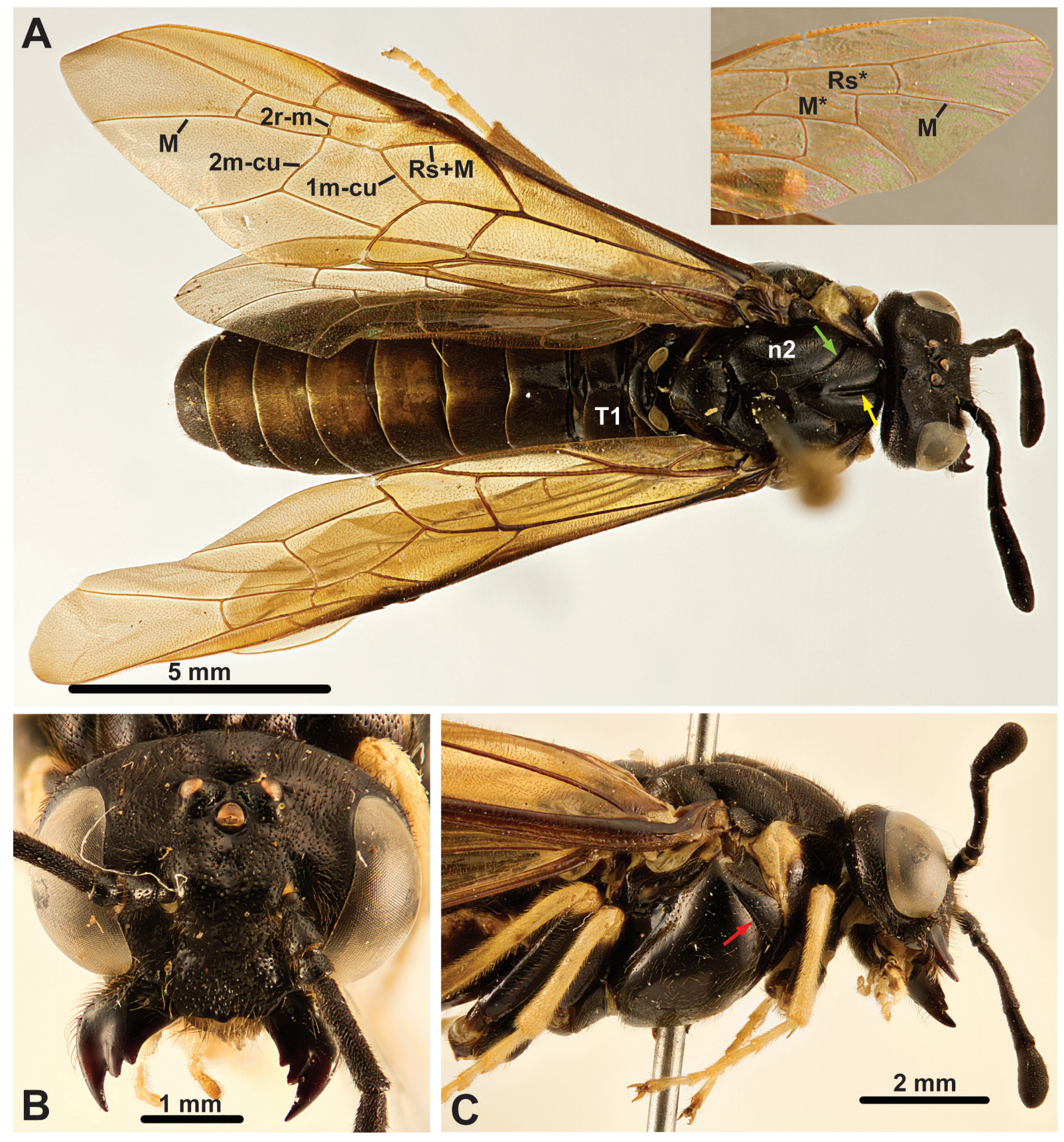

Fig. 13. Pseudabia fusca Schrottky, 1910, ㅇ (NMNH). A. Habitus, dorsal. Insert: tip of hindwing. B. Head, anterior. C. Thorax, lateral. Abbreviations: M, Rs $+\mathrm{M}, 2 \mathrm{r}-\mathrm{m}, 1 \mathrm{~m}-\mathrm{cu}, 2 \mathrm{~m}-\mathrm{cu}=$ wing veins; $\mathrm{M}^{*}$, $\mathrm{Rs}^{*}=$ wing cells; $\mathrm{n} 2=$ mesoscutum; $\mathrm{T} 1=1^{\text {st }}$ abdominal tergum; yellow arrow $=$ median mesoscutal sulcus; green arrow $=$ notaulus; red arrow $=$ mesopleural groove. 
THORAX. Pronotum comparatively high medially, with transverse grove ending in small depression laterally, no lateral groove; pronotum articulating with mesopleuron for short distance ventrolaterally. Dorsal cervical sclerite present. Propectus without lateral projection, propleural sulcus present, medioventral margins of propectus widely separated, posteriorly extended into narrow points. Prosternum laterally extended, continuous with katepisternum which articulate, but does not fuse with propleuron at lateral coxal articulation point. Anterior fore tibial spur straight, simple, not much longer than posterior spur, spurs pointed and sclerotized apically. Mesonotum with distinct median sulcus and deep notauli (Fig. 5C), laterophragmal apodeme not observed, postscutellum absent. Small anterodorsal part of mesopleuron separated from rest by vertical groove (Fig. 5A), prepectus absent as separate sclerite. Horizontal carina absent laterally on mesopleuron. Posterior thoracic spiracle visible in lateral view, situated in incurvation in dorsal margin of mesopleuron. Median midcoxal articulations adjacent, only separated by small wedge of cuticle. Mesofurca not observed. Insertion of mesonoto-metanotal muscle on metanotum not observed; cenchri approx. $2 \times$ as broad as long. Anapleural cleft present, small. Metapleuron fused with abdominal tergum 1 along dorsal margin; posteroventral metapleural apodeme not observed; paracoxal sulcus curving posteriorly, terminating in the middle of the metapleural sulcus;
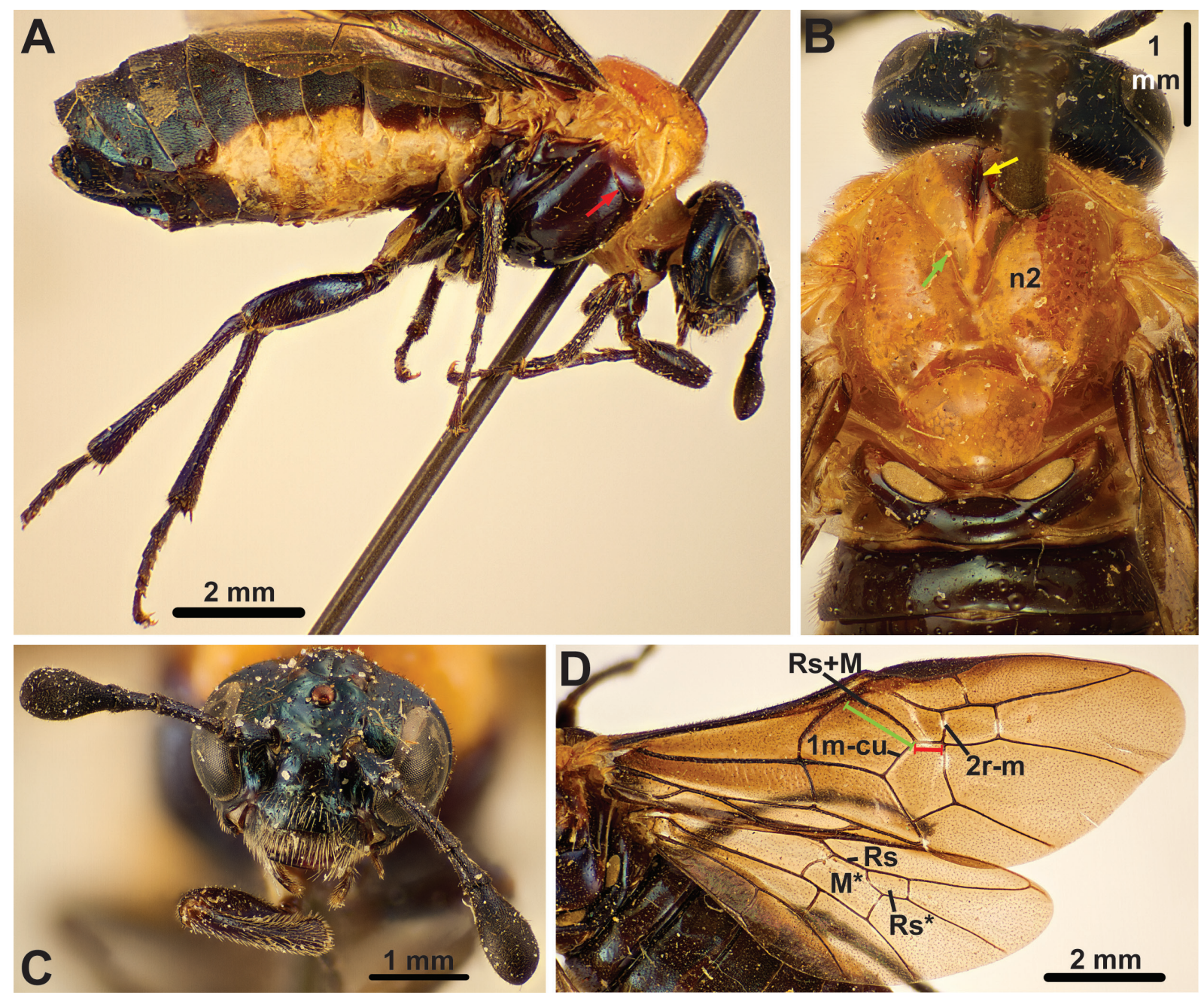

Fig. 14. Pseudopachylosticta subflavata (Kirby, 1882), + (NHRS). A. Body, lateral. B. Fore wing. C. Head, anterior. D. Thorax, dorsal. Abbreviations: Rs, Rs $+\mathrm{M}, 2 \mathrm{r}-\mathrm{m}, 1 \mathrm{~m}-\mathrm{cu}=$ wing veins; $\mathrm{M}^{*}$, Rs* = wing cells; $\mathrm{n} 2$ = mesoscutum; red arrow $=$ mesopleural groove; yellow arrow $=$ median mesoscutal sulcus; green arrow $=$ notaulus. 
metacoxal foramina open dorsally, without metapleural inflection laterally. Metafurca not observed. Hind coxa less than $2 \times$ as long as wide, median carina or spine not observed. Hind femoral ventral spur absent. Hind tibial apical spurs not much longer than apical width of tibia. Hind basitarsomere slightly longer than tarsomeres $2-4$, tarsal claws bifid, teeth of subequal length.

Wings. Fore wing with vein $\mathrm{M}$ joining $\mathrm{Sc}+\mathrm{R}$ close to $\mathrm{Rs}+\mathrm{M}$; vein $2 \mathrm{r}-\mathrm{m}$ posteriorly inserts on cell $2 \mathrm{M}$, very close to anterior end of $2 \mathrm{~m}-\mathrm{cu}$; vein $1 \mathrm{~m}$-cu oriented obliquely, inserting on $\mathrm{M}$ some distance from $2 \mathrm{r}-\mathrm{m}$ (distance $1 \mathrm{~m}-\mathrm{cu}-2 \mathrm{r}-\mathrm{m}$ at least $1 / 2$ distance Rs $+\mathrm{M}-1 \mathrm{~m}-\mathrm{cu}$ on $\mathrm{M}$ ); posterior anal vein present proximally and distally but discontinuous in the middle. Hind wing cell R1 closed; vein M continuous, separating cells Rs and M, cell M not reaching vein Rs; cross vein $2 \mathrm{a}$ absent.

AвDOMEN. Tergum 1 subdivided medially by narrow longitudinal membranous line (Fig. 5C), lateral carina absent, posterior margin straight; tergum 1 not brighter colored than other abdominal terga. Metaphragma not observed. Separation between median terga and lateroterga weakly demarcated, fold most conspicuous on tergum 2 . Cerci triangular, length approx. $1.5 \times$ width mid length. Ovipositor apparatus not observed; Smith (1988: fig. 47) illustrates $1^{\text {st }}$ valvula, with longitudinal line, vertically oriented sawteeth with serrulae, and tip curving dorsally.

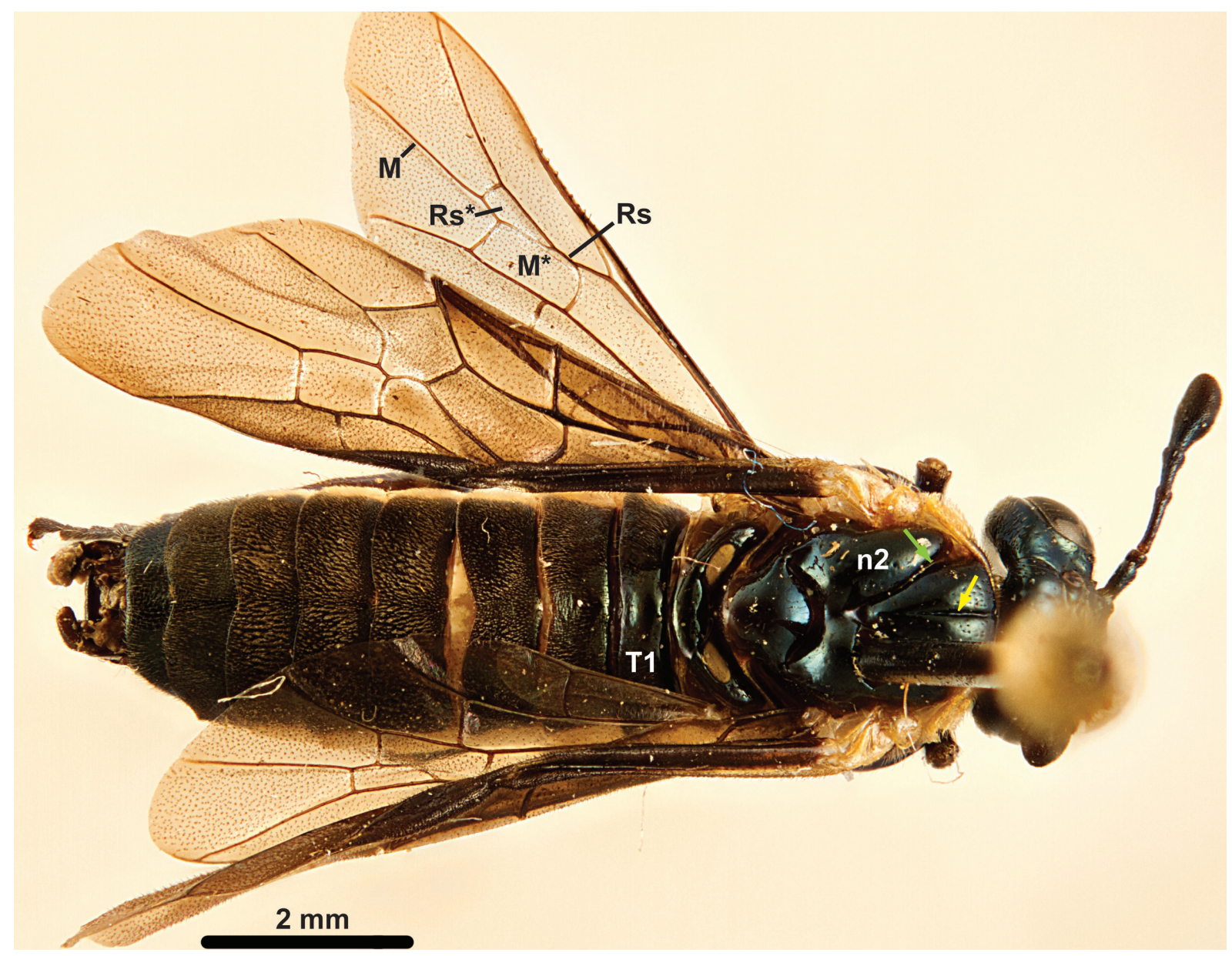

Fig. 15. Pseudopachylosticta subflavata (Kirby, 1882), §, habitus, dorsal view (MHNH). Abbreviations: $\mathrm{M}, \mathrm{Rs}=$ wing veins; $\mathrm{M}^{*}$, Rs* = wing cells; $\mathrm{n} 2=$ mesoscutum; $\mathrm{T} 1=1^{\text {st }}$ abdominal tergum; yellow arrow $=$ median mesoscutal sulcus; green arrow $=$ notaulus. 


\section{Comments}

According to Smith (1988), the holotype was collected in Ypiranga (possibly Ipiranga, São Paulo, Brazil). The other material examined here fits well with the original description of Conde (1932). Conde originally described the species as Pseudabia clypealba, but later transferred it to a separate genus, Brasilabia (Conde 1937); the justification for removing the species from Pseudabia was the medially subdivided abdominal tergum 1 and the small size. The tergum 1 configuration is indeed unique among all Cimbicidae; it might represent a retained plesiomorphy (Blasticotomidae, Diprionidae, most Tenthredinidae and some Argidae and Pergidae display this feature; see Vilhelmsen 2015: character 80) or a reversal compared to other cimbicids. Also diagnostic of Brasilabia clypealba is the eponymous creamy-white clypeus, contrasting with the blackish-brown color of the remainder of the head capsule; all other South American cimbicids have the head capsule uniformly darkly colored in anterior view.

Lopesiana Smith, 1988

Lopesiana Smith, 1988: 221, fig. 48.

Lopesia Conde, 1937: 15, figs 1-2.

Lopesiana thomasi (Conde, 1937)

Figs 6-7

\section{Material examined}

BRAZIL: - Rio de Janeiro: 1 + Itiatiaia, 700 m a.s.1., 2 Mar. 1928, J.F. Zikan leg. (FIOC); 1 ô, same collecting data as preceding but 9 Feb. [19]30 (FIOC); 1 , same collecting data as preceding but 19 Jan. [19]45 (FIOC); 1 +, Gavea, 23 Jan. [19]36 (FIOC).

Redescription (female, male structures only mentioned when differing from females)

MeAsurements. Small to medium-sized sawflies, body length 6 to $9 \mathrm{~mm}$, male smaller than female.

CoLoR. Body coloration predominantly dark brown to black (Figs 6-7). Underside of abdomen creamy white except for apex, white parts extending onto lateral part of terga to various extent. Antennae and mouth parts dark brown; coxae and trochanters variable, femora and tarsi predominantly dark brown to black, tibiae creamy white. Wings hyaline, venation dark brown.

HEAD. Eyes converging ventrally, inner margins slightly incurved (Figs 6B, 7C). Posterior ocelli at level with dorsal margin of eyes. Toruli low on face, distance median ocellus - toruli approx. twice the distance toruli - ventral margin of clypeus; dorsomedian margin of torulus with distinct carina overlapping base of antennomere 1. Epistomal sulcus absent. Clypeus straight, hairy. Gena medially less than half the width of eye, wider dorsally than ventrally. Malar space very low. Occipital carina absent. Sclerotisation between occipital and oral foramina not observed. Antennae with five antennomeres (Figs 6B, 7C); antennomere 1 slightly longer than wide, antennomere 2 approx. as wide as long, antennomere 3 approx. $2 \times$ as long as antennomere 4, antennomere 5 slightly expanded distally. Labrum broad, convex, flat, hairy, distal margin evenly curved. Mandibles less than $1 / 2$ the height of head, number of teeth not observed, inner margin of teeth not serrated. Maxillar palps with six palpomeres (from Conde 1937), longer than labial palps, labial palps with four palpomeres. Postmentum not observed.

THORAX. Pronotum comparatively high medially, with transverse groove extending close to dorsolateral corner, no lateral groove; pronotum fused with mesopleuron for some distance ventrolaterally. Dorsal cervical sclerite present. Propectus without lateral projection, propleural sulcus present, medioventral margins of propectus widely separated, posteriorly extended into narrow points. Prosternum laterally extended, continuous with katepisternum which articulate, but does not fuse with propleuron at lateral 
coxal articulation point. Anterior fore tibial spur straight, simple, not much longer than posterior spur, spurs pointed and sclerotized apically. Mesonotum with median sulcus indistinct, marked as line rather than groove, notauli well developed as grooves (Fig. 6C), laterophragmal apodeme not observed, postscutellum absent. Small anterodorsal part of mesopleuron separated from rest by vertical groove, prepectus absent as separate sclerite. Horizontal carina absent laterally on mesopleuron. Posterior thoracic spiracle covered in lateral view by posterodorsal margin of mesopleuron, short spine projects dorsally just posterior to spiracle (Fig. 7D). Median midcoxal articulations adjacent, only separated by small wedge of cuticle. Mesofurca not observed. Insertion of mesonoto-metanotal muscle on metanotum simple, not on conspicuous structure; cenchri oval, less than $1.5 \times$ as broad as long. Anapleural cleft present, small. Metapleuron fused with abdominal tergum 1 along dorsal margin, line of fusion dark; posteroventral metapleural apodeme not observed; paracoxal sulcus curving posteriorly, terminating in the middle of the metapleural sulcus; metacoxal foramina open dorsally, without metapleural inflection laterally. Metafurca not observed. Hind coxa less than twice as long as wide, median carina or spine not observed. Hind femoral ventral spur absent. Hind tibial apical spurs not much longer than apical width of tibia. Hind basitarsomere at least $1.5 \times$ as long as than tarsomeres $2-4$, tarsal claws bifid, teeth of subequal length.

WINGS. Fore wing with vein $\mathrm{M}$ joining $\mathrm{Sc}+\mathrm{R}$ close to $\mathrm{Rs}+\mathrm{M}$; in females vein $2 \mathrm{~m}$-cu elongate and extends obliquely with anterior end terminating in vein Rs $+M$ proximally to vein $2 \mathrm{r}-\mathrm{m}$ (Fig. 6D), in males vein $2 \mathrm{~m}-\mathrm{cu}$ is short and anteriorly inserts in vein $\mathrm{M}$ well distal to vein $2 \mathrm{r}-\mathrm{m}$; vein $1 \mathrm{~m}-\mathrm{cu}$ oriented obliquely, inserting on $\mathrm{Rs}+\mathrm{M}$ some distance from $2 \mathrm{r}-\mathrm{m}$ (distance $1 \mathrm{~m}-\mathrm{cu}-2 \mathrm{r}-\mathrm{m}$ at least $1 / 3$ distance $\mathrm{M}-1 \mathrm{~m}-\mathrm{cu}$ on Rs $+\mathrm{M}$ ); posterior anal vein present proximally and distally but discontinuous in the middle. Hind wing cell R1 open; vein M continuous, separating cells Rs and M, cell M not reaching vein Rs; cross vein 2a absent.

AвDomen. Tergum 1 continuous medially (Figs 6C, 7A), median carina absent, lateral carina absent, posterior margin slightly incurved; tergum 1 not brighter colored than other abdominal terga. Metaphragma not observed. Separation between median terga and lateroterga weakly demarcated. Cerci oval, length approx. $1.5 \times$ width mid length. Ovipositor apparatus not observed; Conde (1937: fig. 2 ) and Smith (1988: fig. 48) illustrate the $1^{\text {st }}$ valvula, with longitudinal line absent, vertically oriented sawteeth with serrulae present, and tip straight.

\section{Comments}

Originally described as Lopesia thomasi by Conde (1937). According to Conde, the holotype was collected in the Jardin Botanico in Rio de Janeiro in February 1936 and placed in the custody of 'Frey Thomas' (perhaps a monk, i.e., Friar Thomas; the species is named after him). We have not been able to examine the type; the material examined here fits well with the original description. Smith (1988) created the replacement name Lopesiana, as Lopesia Conde, 1937 is a homonym of Lopesia Rübsaamen, 1908 (Diptera, Cecidomyiidae).

Lopesiana thomasi with a body length between 6 and $9 \mathrm{~mm}$ is the smallest of the South American Cimbicidae. Its upper size range overlaps with that of Brasilabia and Pseudopachylosticta. Among Cimbicidae in general, only the Palaearctic genus Corynis has members which are as small as Lopesiana. Apart from the small size, Lopesiana can be separated from the other South American cimbicids by a combination of characters: having non-metallic body coloration, the antenna inserted very low on the face and with the dorsomedian margin of the toruli forming a distinct carina above the antennal bases, the posterior thoracic spiracle being concealed in lateral view (shared with Corynis), having a short, triangular 1st ovipositor valve (compare fig. 48 with figs 42-47 in Smith 1988). The anterior insertion of fore wing vein $2 \mathrm{~m}$-cu on vein Rs $+\mathrm{M}$ female Lopesiana is unique within South American Cimbicidae; the insertion of $2 \mathrm{~m}$-cu proximal to the posterior end of vein $2 \mathrm{r}-\mathrm{m}$ resembles the condition in Abiinae 
and Cimbicinae (see Fig. 2B), that of the males the condition which is observed in other Cimbicidae, including the South American taxa.

Pachylosticta Klug, 1824

Pachylosticta Klug, 1824: 171.

Plagiocera Klug, 1834: 227, pl. II.5.

Pachylosticta albiventris Klug, 1824

Figs 3-4, 8-9

Pachylosticta albiventris Klug, 1824: 171.

Material examined

Holotype

BRAZIL: Ō, 'Rio Jan.' (ZMHB).

\section{Other material}

ARGENTINA: - Misiones: 1 spec., Aristóbulo del Valle, Arroyo Yzcutinga, 29 Nov. 1951, Monros and Willink leg. (IFML).

BRAZIL: - Bahia: 1 ○ૈ, Caetité, 20 Mar. 1980, F.P. Benton leg. (NHML). - Brasilia: 1 †, D. Swainson leg. (NHML). - Distrito Federal: 1 ô (MNRJ), Rosa leg., $1 \hat{\jmath}$ (SDEI). - Espirito Santo: $1 \hat{\jmath}$, Lin[h] ares, Dec. 1970 (MZSP); $1 \hat{\jmath}$, same collecting data as preceding but May 1972 (MNRJ), 1 o, same collecting data as preceding but Jul. 1972, P.C. Elias leg. (MNRJ); 2 $\widehat{\jmath}$, Serra, Manguinhos, 27 Apr. 1922 (FIOC); $1 \hat{O}$, same collecting data as preceding but Nov. 1932, L.T. Col. (FIOC). - Minas

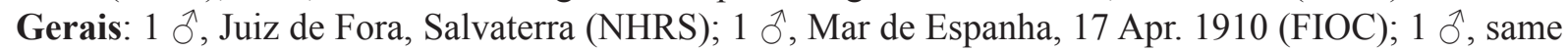
collecting data as preceding but 8 May 1910 (FIOC); 1 o, same collecting data as preceding but 21 Nov.

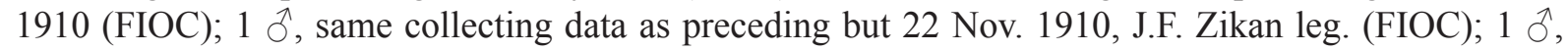
16.[?].1919, J.F. Zikan leg. (FIOC). - Paraná: 1 †, Cavina [not found], Feb. 1947, A. Maller leg. (AMNH); 1 đ, Iguazu, 6 Oct. 1927, R.C. Shannon leg. (NMNH). - Rio Grande do Sul: 1 t, Teutônia, Mar. 1933 (NHRS), 4 q, 1 ภ, same collecting data as preceding but Nov. 1968 (NHRS); 1 q, same collecting data as preceding but Mar. 1977 (NMNH); 1 $\lambda$, same collecting data as preceding [no date] (MNRJ); 1 q, $1 \hat{\jmath}$, same collecting data as preceding (FIOC); 2 우, $3 \hat{\partial} \widehat{\partial}$, same collecting data as

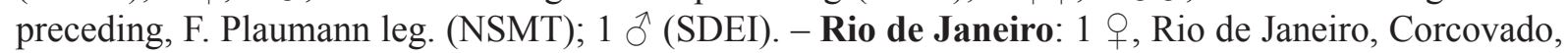
1912-26 (NHML); 1 q, Rio de Janeiro, Estrada das Paineiras, 17 Oct. 1956, C.A. Campos Seabra leg. (MNRJ); $2 \widehat{\partial} \widehat{\partial}$, Rio de Janeiro, Floresta da Tijuca, C.A. Campos Seabra leg. (MNRJ); 1 $\widehat{\alpha}$, Rio de

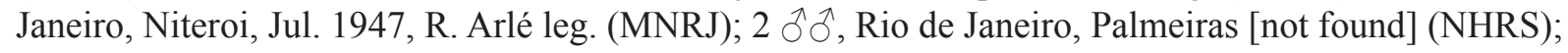
1 , , Rio de Janeiro, Tijuca, Montagnes des Orgues, 1902, E.-R. Wagner leg. (A. violacea? det. D.R. Smith, [19]86 (MNHN); 1 ऽ, Rio de Janeiro (NHMD); 2 우, Rio de Janeiro, V. Olfers leg. (ZMHB).

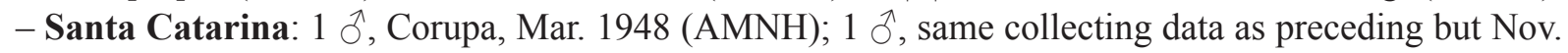
1949, A. Maller leg. (MNRJ); 1 đ̊, Neu Bremen, 21 Mar. 1947 (NHRS); 1 ㅇ, Nova Teutonia, 27 S, 52-58 W, 11 Feb. 1936 (BPBM); 12 §ิ ${ }^{\circ}$, same collecting data as preceding but 8 Mar. 1938 (NHML);

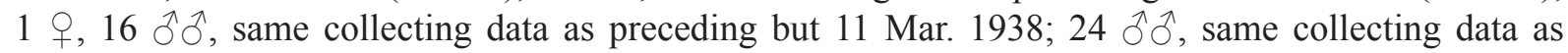

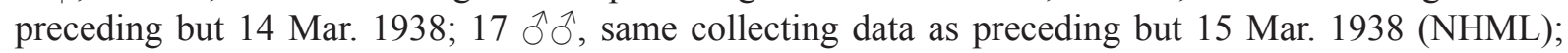
$23 \widehat{\partial} \widehat{\partial}$, same collecting data as preceding but 16 Mar. 1938 (NHML); $18 \widehat{\partial} \widehat{\partial}$, same collecting data as preceding but 17 Mar. 1938; $12 \hat{\widehat{\partial}} \hat{\jmath}$, same collecting data as preceding but 18 Mar. 1938 (NHML); $1 \hat{\jmath}$, same collecting data as preceding but 9 Sep. 1938 (NHML); $1 \hat{\delta}$, same collecting data as preceding but

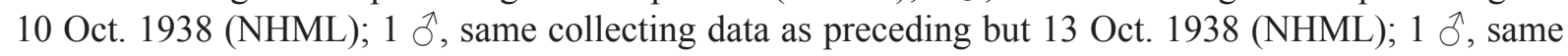
collecting data as preceding but 3 Nov. 1938 (NHML); 1 ${ }^{\Uparrow}$, same collecting data as preceding but 8 Nov. 1938 (NHML); $1 \hat{\jmath}$, same collecting data as preceding but 10 Nov. 1938 (NHML); 1 ○, same collecting 
data as preceding but 11 Nov. 1938 (NHML); 1 \%, same collecting data as preceding but 1939 (NHRS); $2 \hat{\jmath} \hat{\jmath}$, same collecting data as preceding but 1942 (MNRJ); 1 , , same collecting data as preceding but

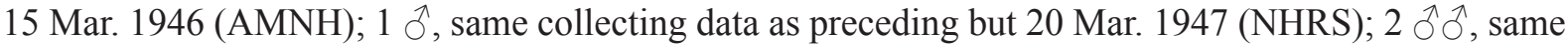
collecting data as preceding but 21 Mar. 1947 (NHRS); $1 \hat{\delta}$, same collecting data as preceding but 22

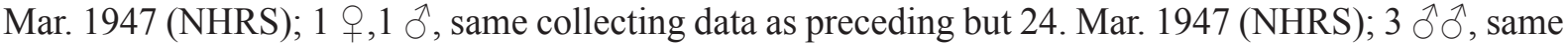

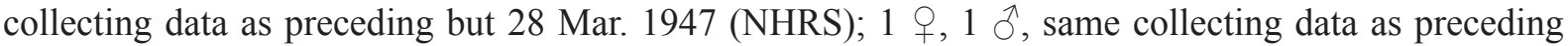

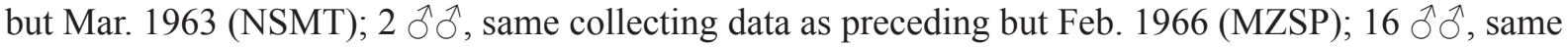

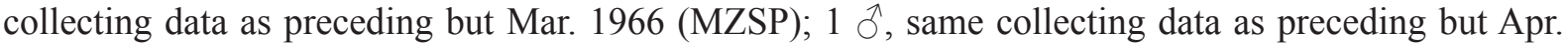

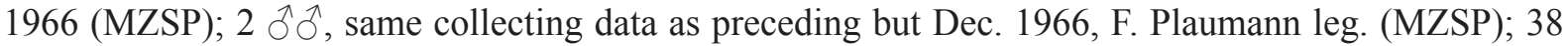

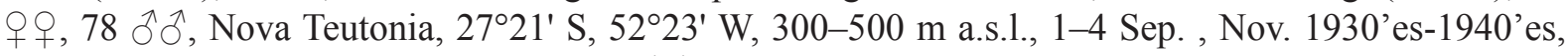

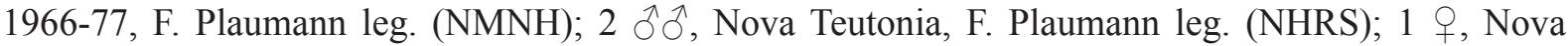
Teutonia, F. Plaumann leg. (NHRS). - São Paulo: 1 spec., Campinas (BPBM); $1 \hat{\jmath}$, Cantareira, 8 Feb. 1940 (MZSP); 1 spec., Piracicaba (BPBM); 1 đ̃, Rio Claro, Nov. 1940 (NHRS); 1 ô, São Paulo, Horto Florestal, 13 Apr. 1962, Lenko \& Reichardt leg. (MZSP). - Province unknown: 1 ô, [?Rigose, Peiro; not mapped], J.F. Zikan leg. (FIOC); 1 Oे, 'Criado no Laboratorio ['reared in the lab']', 4 Jun. 1921

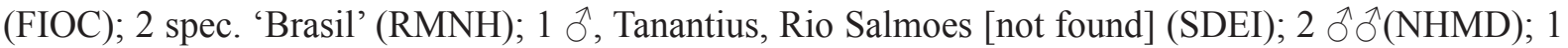

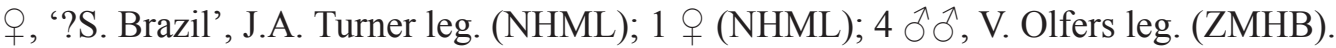

Pachylosticta apicalis (Westwood, 1835)

Figs 2,10

Plagiocera apicalis Westwood, 1835: 51.

Plagiocera leachii Spinola, 1840: 134.

\section{Material examined}

Holotype

BRAZIL: + , 'Rio Jan.’ (OUMNH).

\section{Other material}

BRAZIL: - Espirito Santo: 2 우, Córrego do Itá, Nov. 1956, W. Zikan leg. (MNRJ). - Minas Gerais: 1 ․, Vicosa, 9 Jan. 1975, J. Freira leg. (MNRJ). - Parana: 2 우, Rolândia, Oct. 1947 (AMNH); 1 ㅇ, same collecting data as preceding but Jan. 1950 (MNRJ); 1 q, same collecting data as preceding but Nov. 1974, A. Maller leg. (NMNH); 1 + , São João, Preta Tineas, Sep.-Oct. 1928, E. May leg. (MNRJ). - Rio de Janeiro: 1 \&, Grajahu [Grajaú], 8 Dec. 1940, Lopes and Oliveira leg. (NHRS); 1 đ̊, 1906(?), L. Fairmaire leg. (MNHN). - São Paulo: 1 , Cantareira, Nov. 1951 (NHRS). - Province unknown: 1 , 'Brasilia', H. des Dreneuf leg. (RMNH); 1 \& (MIZT; holotype of Pachylosticta leachii); 1 \& (NHRS).

Pachylosticta plaumanni Malaise, 1939

Fig. 11

\section{Material examined}

Holotype

BRAZIL: + , 'S:ta Cathar., Nova Teutonia' (NHRS).

\section{Other material}

BRAZIL: - Espirito Santo: 1 q, Córrego do Itá, Nov. 1954, W. Grossmann leg. (MNRJ); 1 q, Córrego do Itá, Nov. 1956, W. Zikan leg. (MNRJ). - Rio de Janeiro: 1 q, Niteroi, Morro do Cavalão, 11 Nov. 1946, Arté leg. (NHRS). - Santa Catarina: 1 + , Nova Teutonia, 2711' S, 52 $23^{\circ}$ W, 300-500 m a.s.1., Nov. 1966, F. Plaumann leg. (NMNH). - São Paulo: 1 +, Cantareira, Sep. 1951 (NHRS); 1 q, São Paulo, 9 May 1975, S.A. Vanin leg. (MZSP). 
PARAGUAY: 1 +, San Rafael National Park, Ynambú, 17 Nov. 2005 (NMNH).

Pachylosticta tibialis Klug, 1824

Fig. 12

Pachylosticta tibialis Klug, 1824: 173. Type species, designated by Rohwer (1911).

Amasis dilatata Lepeletier \& Serville, 1828 in Latreille et al. (1828): 574.

\section{Material examined}

\section{Holotype}

BRAZIL: 'Brasilia', ô, V. Olfers leg. (ZMHB).

\section{Other material}

BRAZIL: - Bahia: 1 ô, Cepec Itabuna, Reserva Botanica, 13 Dec. 1981, F.P. Benton leg. (NHML). - Rio

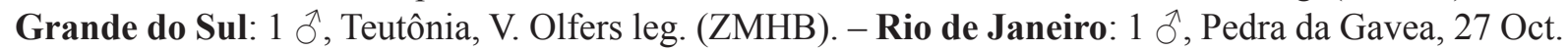
1936 (NHRS); 4 spec., Rio de Janeiro, Nov. 1914 (CMNH); 1 गे, same collecting data as preceding but

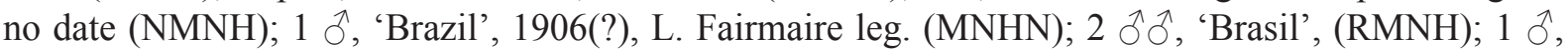

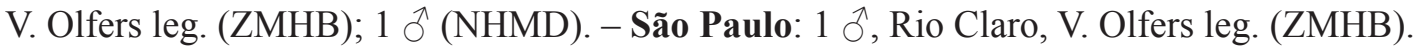

\section{Pachylosticta violacea Klug, 1824}

Fig. 12

Pachylosticta violacea Klug, 1824: 174.

Pachylosticta chalybea Perty, 1833: 129, pl. 26.2.

Plagiocera thoracica Klug, 1834: 228, pl. II.5.

\section{Material examined}

\section{Holotype}

BRAZIL: $\widehat{\partial}$ (ZMHB).

\section{Other material}

ARGENTINA: - Misiones: 1 spec., Bernardo de Irigoyen, 12 Nov. 1973, Escobar-Claps leg. (IFML); $1 \hat{\jmath}$, San Antonio, Dec. 1973 (MAFC); $2 \hat{\jmath} \widehat{\jmath}$, same collecting data as preceding but Fritz leg. (IBGE); 1 ô, San Antonio, Fritz leg (MAFC); 1 spec., San Pedro, 16 Nov. 1973, Willink and Tomsic leg. (IFML); 1 spec., Tobunas, 3 Dec. 1951, Monros and Willink leg. (IFML).

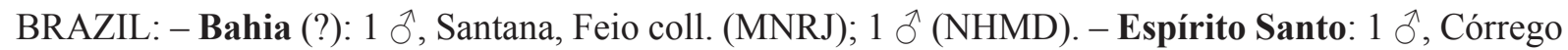
do Itá, Nov. 1956, W. Zikan leg. (MNRJ); 1 ð, 1906, Z. Garbe leg. (MZSP). - Minas Gerais, 1 స

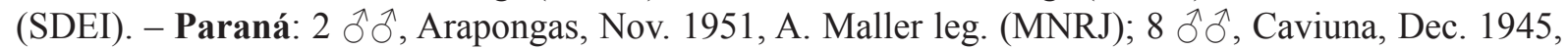
A. Maller leg. (AMNH), 1 ${ }^{\lambda}$, same collecting data as preceding (NMNH); 1 గ, Rolândia, Dec. 1945, A. Maller leg. (AMNH); $2 \hat{\jmath}$, same collecting data as preceding but Nov. 1947 (AMNH), $2 \lesssim \widehat{\jmath}$, same collecting data as preceding but Dec. 1947 (AMNH); $1 \hat{\jmath}$, same collecting data as preceding but Mar. 1948 (NMNH); 1 §े, same collecting data as preceding but Apr. 1948 (AMNH); 1 ठे, same collecting data as preceding but Apr. 1949 (AMNH); 10 , same collecting data as preceding but no date (AMNH);

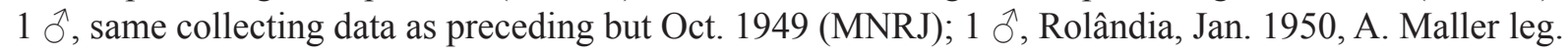
(MNRJ); 2 đ̊̊, Rolândia, Nov. 1951, A. Maller leg. (MNRJ); 1 spec., Terra Boa, 23 Dec. 1983 (INPA); 1 spec., same collecting data as preceding but 27 Dec. 1983 (INPA). - Piauí: 1 § (ZSM; lectotype of Pachylosticta chalybea); 1 \ (ZSM; paralectotype of Pachylosticta chalybea). - Rio Grande do Sul:

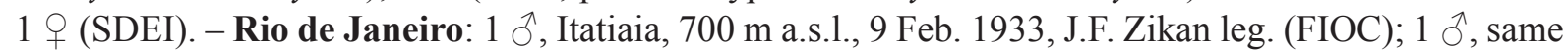
collecting data as preceding but 11 Feb. 1933 (FIOC); 1 ô, same collecting data as preceding but 5 Feb. 
1936 (FIOC); $1 \hat{\jmath}$, same collecting data as preceding but 20 Jul. 1942 (FIOC); $2 \hat{\jmath} \hat{\partial}$, same collecting data as preceding but Nov. 1959 (MNRJ); 1 Oे, Niteroi, N4725, G. de Entom. Esc. Sup. Agri., 15 Jul. 1917, Jacintho leg. (MNRJ); 1 ภ, Tijuca (NHRS); 3 $ぇ$, Oct. 1893 (NHRS); 1 (NHRS). - Santa Catarina: $2 \AA \widehat{\jmath}$ (NHRS). - São Paulo: $1 \hat{\jmath}$, Anhembi, Faz. Bar. Rico, 1 Mar. 1960, A. Barroso leg.

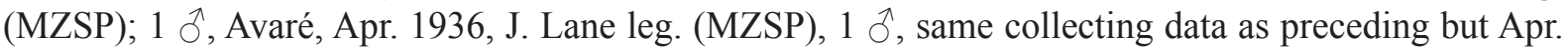
1956 (NMNH); 1 đ̊, Baguassu, Feb. 1959 (MZSP); 1 ô, Botucatu, 9 Feb. 1911, Marques leg. (MNRJ);

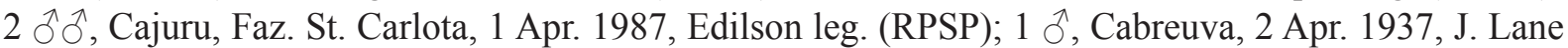

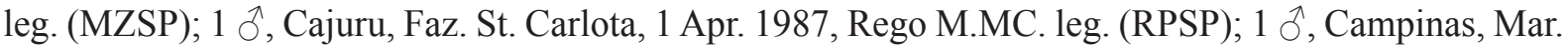

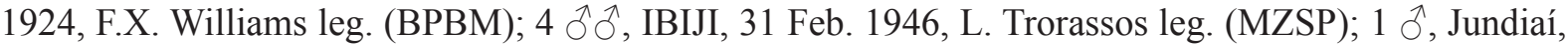
Nov. 1900 (NMHH); 1 §̃, Jundiaí (SDEI); 1 spec., Piracicaba (BPBM); 1 spec.?, Piraju, 10 Mar. 1965,

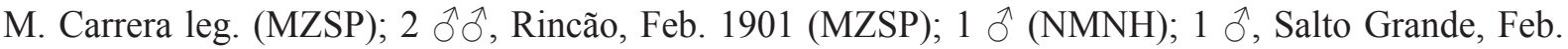
1911, Leuderwaldt leg. (MZSP); 1 ð, Valle du Rio Pardo, Dec. 1898, E. Gounelle leg. (MNHN); 1 ๙

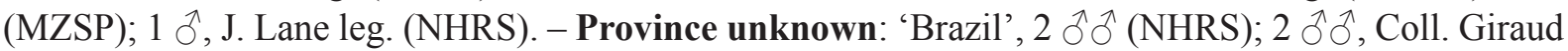

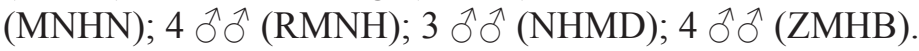

\section{Pachylosticta sp.}

Fig 12

Males with partly reddish coloration on thorax or abdomen.

\section{Material examined}

BRAZIL: - Espirito Santo: 2 $\widehat{\partial}$, Córrego do Itá, Nov. 1956, W. Zikan leg. (MNRJ). - São Paulo: 1 Ĵ, Valle du Rio Pardo, Dec. 1898, E. Gounelle leg. (A. plaumanni? det. D.R. Smith, 1986) (MNHN).

Redescription (female, male structures only mentioned when differing from females).

Measurements. Comparatively large and robust sawflies, body length 12-16 mm.

CoLor. Males (Figs 9, 12) with dark blue metallic coloration on most of body, rarely with parts of thorax (Fig. 12B) or abdominal tergum 4 to 6 reddish brown (Fig. 12D). Females (Figs 8, 10-11) with extensive reddish-brown coloration on large parts of thorax and also often anterior abdomen, remaining body parts dark blue metallic. Wings mostly darkly infuscated in both sexes, in female $P$. apicalis infuscation distally contrast with more hyaline wing coloration proximally (Fig. 10A).

HEAD. Eyes at most slightly converging ventrally, inner margins at most slightly incurved. Posterior ocelli at level with dorsal margin of eyes (Figs 8B, 10B, 11B). Toruli in middle of face, approx. halfway between median ocellus and ventral margin of clypeus. Epistomal sulcus absent. Clypeus with ventral margin straight. Gena medially less wide than width of eye, wider dorsally than ventrally. Malar space very low. Occipital carina absent. Sclerotisation between occipital and oral foramina present. Antennae with five antennomeres; antennomere 1 approx. $2 \times$ as long as wide, antennomere 2 approx. as wide as long, antennomere $31.2-1.5 \times$ as long as antennomere 4 , antennomere 5 slightly expanded distally; females of $P$. albiventris and $P$. apicalis with elongate, lighter colored area on ventral side of antennomere 5. Labrum broad, convex, hairy, raised in the middle under ventral margin of clypeus, distal margin straight or slightly curved. Mandibles less than $1 / 2$ the height of head in both sexes, with three well developed teeth on right, proximal tooth less developed on left mandible, inner margin not serrated. Maxilla with stipes of approx. equal width throughout, palps with four palpomeres, shorter than labial palps. Labial palps with three palpomeres, palps inserting at level with maxillary palps. Postmentum narrow, at least $3 \times$ as long as wide.

Thorax. Pronotum usually comparatively high medially, with transverse groove extending from submedially on ventral margin to posterodorsal corner of pronotum; lateral groove continuous with 
transverse, extending parallel to lateral margin of pronotum until ventral to anterior thoracic spiracle where it diverges medially to ventral margin of pronotum; pronotum fused with mesopleuron for short distance ventrolaterally. Dorsal cervical sclerite present. Propectus without lateral projection, propleural sulcus present, medioventral margins of propectus widely separated, posteriorly extended into narrow points. Prosternum laterally extended, katepisterna separate sclerites not reaching lateral coxal articulation point. Anterior fore tibial spur straight, simple, not much longer than posterior spur, spurs pointed and sclerotized apically. Mesonotum with distinct median sulcus and deep notauli (Figs 8A, 11A), laterophragmal apodeme short, postscutellum absent. Small anterodorsal part of mesopleuron separated from rest by vertical groove (Figs 8C, 9A, 12A, C-D), prepectus absent as separate sclerite. Horizontal carina absent laterally on mesopleuron. Posterior thoracic spiracle visible in lateral view, situated in incurvation in dorsal margin of mesopleuron (Figs 8C, 10C). Median midcoxal articulations adjacent, only separated by small wedge of cuticle. Mesofurca with mesospina and elongate anterior and lateral arms. Insertion of mesonoto-metanotal muscle on metanotum not on conspicuous structure; cenchri approx. $2.2-3 \times$ as broad as long. Anapleural cleft present, small. Metapleuron fused with abdominal tergum 1 along dorsal margin; posteroventral metapleural apodeme absent; paracoxal sulcus curving posteriorly, terminating in the middle of the metapleural sulcus; metacoxal foramina open dorsally, with slight metapleural inflection laterally. Metafurca with anterior arms hardly developed, lateral arms elongate. Hind coxa less than twice as long as wide, median carina or spine absent. Hind femoral ventral spur absent. Hind tibial apical spurs shorter than apical width of tibia. Hind basitarsomere longer than tarsomeres 2-4 (Figs 9A, 12A, C), tarsal claws bifid, inner tooth variable.

Wings. Fore wing with pterostigma extended anteriorly and thickened in male (Figs 9A, 12); vein M joins $\mathrm{Sc}+\mathrm{R}$ close to Rs $+\mathrm{M}$; vein $2 \mathrm{r}-\mathrm{m}$ posteriorly inserts on cell $2 \mathrm{M}$, some distance proximally to anterior end of $2 \mathrm{~m}$-cu; vein $1 \mathrm{~m}$-cu oriented obliquely to almost parallel with longitudinal axis of wing, inserting on Rs $+\mathrm{M}$ close to posterior insertion of $2 \mathrm{r}-\mathrm{m}$ (distance $1 \mathrm{~m}-\mathrm{cu}-2 \mathrm{r}-\mathrm{m}$ at most $1 / 4$ distance $\mathrm{M}-1 \mathrm{~m}$-cu on Rs+M; Figs 2A, 8A, 9A); posterior anal vein present proximally and distally but discontinuous in the middle. Hind wing cell R1 open, except in P. plaumanni and some females of $P$. albiventris; vein M continuous, separating cells Rs and $\mathrm{M}$, cell $\mathrm{M}$ not reaching vein Rs; cross vein 2a absent.

ABDOMEN. Tergum 1 not subdivided medially (Fig. 10A), median carina absent, lateral carina absent, posterior margin slightly curved; tergum 1 not brighter colored than other abdominal terga. Metaphragma continuous medially, of approx. equal height throughout, median foramen absent. Lateroterga around abdominal spiracles separated from median terga as demarcated by conspicuous fold (Fig. 3A). Cerci variable, length less than $2 \times$ width mid length. Ovipositor apparatus with $1^{\text {st }}$ valvula having longitudinal line, sawteeth strongly asymmetric, broadened in ventral view, slanted proximally, serrulae absent (Smith 1988: figs 42-44; Vilhelmsen 2018: fig. 19B); tip of $1^{\text {st }}$ and $2^{\text {nd }}$ valvulae only slightly curving dorsally; ventral margin with tufts of setae along its length, tufts not on extended lobes (Vilhelmsen 2018: figs 18D, 19E).

\section{Comments}

Pachylosticta Klug, 1824 is the first genus of South American Cimbicidae described and hence the nominal genus of the Pachylostictinae. The most striking feature of the genus is the thickened and anteriorly extended pterostigma in the males. The absence of this feature in the females resulted in the genus Plagiocera Klug, 1834 being proposed for Plagiocera thoracica; judging from the illustration in Klug (1834: plate II, fig. 5) the description was based on what appears to be a female of Pachylosticta albiventris. Only much later was the connection between the two genera made; the earliest reference to Plagiocera as a synonym of Pachylosticta we have come across is in Konow (1907). An autapomorphy for the genus displayed by both sexes is the orientation of fore wing vein $1 \mathrm{~m}-\mathrm{cu}$, which inserts on vein Rs $+\mathrm{M}$ distally, so that the distance between the insertions of $2 \mathrm{r}-\mathrm{m}$ and $1 \mathrm{~m}-\mathrm{cu}$ on Rs $+\mathrm{M}$ is at most $1 / 4$ of the distance between the insertions of $\mathrm{M}$ and $1 \mathrm{~m}-\mathrm{cu}$ on $\mathrm{Rs}+\mathrm{M}$. 
Pachylosticta is most similar to Pseudopachylosticta among the South American Cimbicidae. Both have striking coloration patterns, blue-black metallic body sometimes with paler coloration on some parts of the males and extensive reddish-brown areas on the thorax and sometimes abdomen in the females. The other South American genera are comparatively drab in appearance. Furthermore, Pachylosticta and Pseudopachylosticta both have the labrum raised in the middle and reduced maxillary and labial palps, with four and three palpomeres, respectively. Apart from the fore wing characters, Pachylosticta differs from Pseudopachylosticta in having the hind wing cell RS larger and cell M not reaching vein Rs, and the hind basitarsomere is longer than tarsomeres 2-4 combined in Pachylosticta spp. Finally, Pachylosticta spp. are larger (body length may exceed $1.5 \mathrm{~cm}$ ) and more compact than Pseudopachylosticta or any other South American Cimbicidae. Pseudabia fusca reaches a body length similar to Pachylosticta spp., but is more slender in appearance.

Conde (1937, 1940) and Malaise (1939) disagreed strongly on the separation of males in Pachylosticta. Conde (1937) regarded all three species ( $P$. albiventris, $P$. tibialis, $P$. violacea) originally described by Klug (1824) as one species, perceiving no significant differences in the male genitalia and regarding the color variation between them as a variation within P. tibialis, the type species. In contrast, Malaise (1939) correlated the color differences with a variation in the male genitalia and recognized three species; this scheme was confirmed by Smith (1988) and is also followed here (see also the key). Pachylosticta violacea is characterized by being completely darkly colored with no pale markings (Fig. 12C); male $P$. albiventris has an extensive creamy-white to orange patch on the underside of the abdomen (sternum and laterotergum 2 to 4/5; Fig 9A); P. tibialis has paler coloration on the upper part of the mesopleuron and the distal part of the legs (tibiae and most of the tarsi; Fig. 12A).

The two male Pachylosticta sp. from Espirito Santo, Córrego do Itá (in MNRJ) differ from all other males examined here in having a reddish-brown band formed by the different color of abdominal terga 4-6 across the abdomen (Fig. 12D); we have not placed them to species. The male from São Paulo, Valle du Rio Pardo (in MNHN) was identified by D.R. Smith as 'P. plaumanni?' (see also Smith 1988: p. 219). The thorax of this specimen is predominantly reddish brown with the following parts dark brown to black (Fig. 12B): left half of pronotum, left half of propectus, left hind leg, most of mesonotum (including mesoscutellum) except area between the median mesoscutal sulcus and right notaulus, posterior half of both tegulae, both postspiracular sclerites, posterodorsal margin of left mesepimeron (adjacent to the posterior thoracic spiracle), left $2 / 3$ of metanotum (including the metascutellum). The right half of the $1^{\text {st }}$ abdominal tergum is reddish brown, the left dark brown. In addition, on the right apical antennomere there is an elongate lightly colored area ventrally (Fig. 12B, yellow arrow), similar to the one observed in female $P$. albiventris an $P$. apicalis (see below); the left apical antennomere is uniformly darkly colored as in all other male Pachylosticta spp. observed. The asymmetrical, harlequin-like coloration of this specimen is probably aberrant and we refrain from suggesting a species identification based on the coloration alone. Another aberrantly colored specimen is a $P$. albiventris male from Caetité, Bahia, Brazil (NHML); it has the distinctive pale anterior abdominal sternites but reddish brown markings posteriorly on the pronotum, in the middle of the mesonotum along the notauli and dorsally on the mesoand metapleuron as well as the proximal part of the hind tibia creamy white.

Female Pachylosticta spp. can also be separated by color differences on the body and wings. Pachylosticta albiventris and $P$. apicalis usually have the pro- and mesothorax reddish brown throughout (Figs 8A, 10A), whereas P. plaumanni has the median part of the pronotum and the mesoscutum darkened (Fig. 11A). However, the female Pachylosticta albiventris from Linhares has the mesonotum as well as the lower parts of the mesopleura darkened; Smith (1988) reported observing a similar color variation in the females of this species. Pachylosticta albiventris has the metathorax and abdomen uniformly blue-black metallic (Fig. 8A), whereas the other two species have only the apex of the abdomen (from segment 4 or 5) darkened (Figs 10A, 11A). In the fore wing, P. apicalis has the tip darkly infuscate contrasting with 
the hyaline base (Fig. 10A), whereas the other two species have the fore wings more or less uniformly infuscate (Fig. 8A). Finally, in P. albiventris and P. apicalis there is an elongate lightly colored area on the ventral side of the apical antennomere (Figs $8 \mathrm{~B}-\mathrm{C}, 10 \mathrm{~B}-\mathrm{C}$ ); this is missing from P. plaumanni (Fig. 11B) and male Pachylosticta spp. (but see above); the function is unknown. Interestingly, this feature is illustrated in Klug (1834: plate II, fig. $5 \mathrm{~g}$ ) in the description of Plagiocera thoracica, but not mentioned in the text.

With five currently recognized species, Pachylosticta is the only non-monotypic genus of South American Cimbicidae, comprising over half the species. Nevertheless, there is a possibility that the diversity of the genus is overestimated, as males and females have only been associated for the most common species, . albiventris. Of the remaining species, $P$. apicalis and P. plaumanni are known only from females, whereas $P$. tibialis and $P$. violacea are known only from males. Unfortunately, no morphological characters have been discovered that can be used to link any of these species to each other. In addition, the affinity of males with coloration more resembling that of the females has not been decided. Pachylosticta violacea males have been collected in the same localities as both P. apicalis (Parana, Rolândia) and P. plaumanni (Espirito Santo, Córrego do Itá), thus providing little evidence for associating $P$. violacea with any of the females of the two other species. The aberrantly colored Pachylosticta spp. males were also collected in Espirito Santo, Córrego do Itá. In general, the distributions of the described species of Pachylosticta are broadly overlapping (Fig. 16), thus providing no help for associating the sexes. DNA barcoding could potentially help to associate males and females in Pachylosticta spp. and decide if some species have different color morphs in one sex or the other. Unfortunately, the material available for this study is somewhat dated and it might not be possible to make adequate extractions from it.

Pseudabia Schrottky, 1910: 168.

Pseudabia Schrottky, 1910

Enslinia Jörgensen, 1913: 254.

Pseudabia fusca Schrottky, 1910

Figs 1, 13

Pseudabia fusca Schrottky, 1910: 168.

Enslinia holmbergi Jörgensen, 1913: 254.

\section{Material examined}

ARGENTINA: - Misiones: 1 क , Bonpland, 7 Nov. 1910, Jörgensen leg. (MLPA; holotype of Enslinia holmbergi).

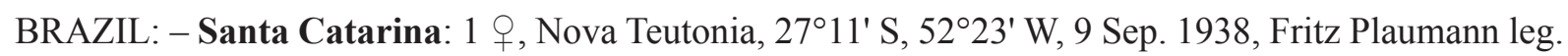
(NHML); 1 , same collecting data as preceding but Sep. 1972 (NMNH). - Santa Catarina: 1 , , Nova Teutonia, 7 Nov. 1969, Fritz Plaumann leg. (NMNH).

Redescription (female, male unknown)

MEASUREMENTs. Large and elongate sawfly, body length 15-16 mm.

Color. Coloration uniformly black to dark brown with a few lighter brown to creamy-white areas on lateral parts of pronotum, posteriorly on dorsal part of abdominal terga and on lateroterga (Fig. 13A). Legs proximally dark brown to black, creamy white from distal part of femora. Wings weakly and uniformly infuscate. 
HEAD. Eyes slightly converging ventrally, inner margins slightly incurved. Posterior ocelli at level with dorsal margin of eyes. Toruli in middle of face, slightly closer to median ocellus than to ventral margin of clypeus (Fig. 13B). Epistomal sulcus absent. Clypeus ventral margin straight, with slight protrusion in the middle. Gena medially less wide than width of eye, wider dorsally than ventrally. Malar space very low. Occipital carina absent. Sclerotisation between occipital and oral foramina present. Antennae with five antennomeres (Figs 1A, 13C); antennomere 1 approx. $2 \times$ as long as wide, antennomere 2 approx. as wide as long, antennomere $31.8 \times$ as long as antennomere 4 , antennomere 5 slightly expanded distally. Labrum broad, convex, hairy, flat, distal margin slightly curved. Mandibles less than $1 / 2$ the height of head, with three teeth each, inner margin not serrated (Fig. 13B). Maxilla with stipes of approx. equal width throughout, palps with six palpomeres, longer than labial palps. Labial palps with four palpomeres, palps inserting at level with maxillary palps. Postmentum drop-shaped, approx. $2 \times$ as long as wide.

Thorax. Pronotum comparatively high medially, with transverse groove extending from submedially on pronotum to posterodorsal corner; lateral groove continuous with transverse, extending ventrally on pronotum until ventral to anterior thoracic spiracle where it terminates; pronotum fused with mesopleuron ventrolaterally of spiracle from halfway between spiracle and ventrolateral corner of pronotum. Dorsal cervical sclerite present. Propectus without lateral projection, propleural sulcus present, medioventral margins of propectus widely separated, posteriorly extended into narrow points. Prosternum laterally extended, continuous with katepisternum which articulate, but does not fuse with propleuron at lateral coxal articulation point. Anterior fore tibial spur straight, simple, not much longer than posterior spur, spurs pointed and sclerotized apically. Mesonotum with distinct median sulcus and deep notauli (Fig. 13A), laterophragmal apodeme not observed, postscutellum absent. Small anterodorsal part of mesopleuron separated from rest by vertical groove (Fig. 13C), prepectus absent as separate sclerite. Horizontal carina absent laterally on mesopleuron. Posterior thoracic spiracle visible in lateral view, situated in incurvation in dorsal margin of mesopleuron. Median midcoxal articulations adjacent, only separated by small wedge of cuticle. Mesofurca not observed. Insertion of mesonotometanotal muscle on small projection on anterior margin of metanotum; cenchri approx. $2 \times$ as broad as long. Anapleural cleft present, small. Metapleuron fused with abdominal tergum 1 along dorsal margin; posteroventral metapleural apodeme not observed; paracoxal sulcus curving posteriorly, terminating in the middle of the metapleural sulcus; metacoxal foramina open dorsally, without metapleural inflection laterally. Metafurca not observed. Hind coxa less than twice as long as wide, median carina or spine not observed. Hind femoral ventral spur absent. Hind tibial apical spurs shorter than apical width of tibia. Hind basitarsomere shorter than tarsomeres $2-4$, tarsal claws bifid, teeth of subequal length.

Wings. Fore wing with vein $\mathrm{M}$ joining $\mathrm{Sc}+\mathrm{R}$ close to Rs $+\mathrm{M}$; vein $2 \mathrm{r}-\mathrm{m}$ posteriorly inserts on cell $2 \mathrm{M}$, very close to anterior end of $2 \mathrm{~m}$-cu (Fig. 13A); vein $1 \mathrm{~m}$-cu oriented obliquely, inserting on Rs $+\mathrm{M}$ some distance from $2 \mathrm{r}-\mathrm{m}$ (distance $1 \mathrm{~m}-\mathrm{cu}-2 \mathrm{r}-\mathrm{m}$ at least $1 / 2$ distance $\mathrm{M}-1 \mathrm{~m}-\mathrm{cu}$ on $\mathrm{Rs}+\mathrm{M}$ ); posterior anal vein present proximally and distally but discontinuous in the middle. Hind wing cell R1 closed; vein $M$ discontinuous, making cells Rs and M partly confluent (Fig. 13A insert), cell M not reaching vein Rs; cross vein $2 \mathrm{a}$ absent.

AвDomen. Tergum 1 not subdivided medially (Fig. 13A), short median carina present, lateral carina absent, posterior margin with slight incurvation medially; tergum 1 not brighter colored than other abdominal terga. Metaphragma not observed. Lateroterga around abdominal spiracles separated from median terga as demarcated by conspicuous fold. Cerci triangular, length approx. equals width at base. Ovipositor apparatus not observed; Smith (1988: fig. 46) illustrates $1^{\text {st }}$ valvula, with longitudinal line, vertically oriented sawteeth with serrulae, and tip slightly curving dorsally. 


\section{Comments}

The holotype appears to be lost (Smith 1988), according to Malaise (1939: 27) "All the types of Schrottky have been destroyed in a civil war". The type locality given by Schrottky (1910) is Puerti [sic, probably Puerto] Bertoni, Paraguay. Malaise (1939) also listed Nova Teutonia, Brazil, as a locality. Jörgensen (1913) described Enslinia holmbergi from Bonpland, Misiones, Argentina; Conde (1932) synonymized this species with Pseudabia fusca, a decision that was followed by Smith (1988). In contrast, Malaise (1939) considered the two taxa should be kept separate, citing differences from the descriptions of Schrottky (1910) and Jörgensen (1913) in relative antennomere proportions head width, mesonotal sculpture and sawsheaths ( $3^{\text {rd }}$ valvulae). The present authors follow Smith (1988).

The specimens examined here fit well with the description of Schrottky (1910). The NHML specimen has a broad creamy-white band along each side of the abdomen, covering most of the lateroterga; in contrast, the NMNH specimens have only a narrow stripe along the bend between the median terga and the lateroterga. Jörgensen (1913) and Smith (1988) considered the abdomen/body to have a metallic sheen ("obscure metalico",'mostly metallic green'). The specimens examined by us look more brownish black, with at most a faint metallic sheen on the abdomen; perhaps the color changes as the specimen ages. Schrottky (1910) and Jörgensen (1913) described Pseudabia fusca/Enslinia holmgreni as having eight or seven antennomeres, respectively, with the apical 3-4 forming the apical club; Smith (1988: fig. 33) illustrated $P$. fusca as having five antennomeres, with a subdivision in the middle of the club. Indeed several subdivisions can be discerned in the specimens we have examined, but these are never distinct enough to separate antennomeres within the club as clearly as between it and the four proximal antennomeres. Hence the antenna is regarded as comprising five antennomeres, as in all other South American Cimbicidae.

The most distinctive feature of Pseudabia fusca is the interruption of vein $\mathrm{M}$ in the hind wings, which makes cells Rs and M partly continuous; this is a unique feature within Cimbicidae. The general habitus is also slightly different from the other South American species in that $P$. fusca, even though it has a body length similar to Pachylosticta spp., appears to be more slender than the comparatively compact and/or shorter members of the other cimbicid species. Among the South American Cimbicidae, P. fusca is the only species to have a well-developed median carina on abdominal tergum 1 .

Pseudopachylosticta Mallach, 1929

Pseudopachylosticta subflavata (Kirby, 1882)

Figs 14-15

Amasis subflavata Kirby, 1882: 17, pl. I.9.

Amasis brasiliensis Mocsáry, 1909: 2.

Amasis neotropica Mocsáry, 1909: 2.

Pseudopachylosticta brunnescens Mallach, 1929: 287.

Pseudopachylosticta leucogaster Mallach, 1929: 286, figs 1,3.

\section{Material examined}

Holotype

ARGENTINA: - Córdoba: $\widehat{\jmath}$ (NHML).

\section{Other material}

ARGENTINA: - Chaco/Santiago del Estero: 1 q (NHRS). - Córdoba: 1 q, W.M. Davis leg. (NMNH); 3 spec., W.M. Davis leg. (MCZ). - Formosa: 1 , , Riacho Pilaga, Ruta 11, 26 km NW of Formosa, 11 Aug. 1972, Porter, Stange and Fidalgo leg. (NMNH); 1 spec., same collecting data as preceding but 
no date (IFML). - Jujuy: 1 q, Volcán, Feb. 1926 (NHRS). - Misiones: 1 q, Dos de Mayo, Dec. 1973, Fritz leg. (IBGE). - Salta: 1 +, Steinbach leg. (ZMHB; holotype of Pseudopachylosticta brunnescens);

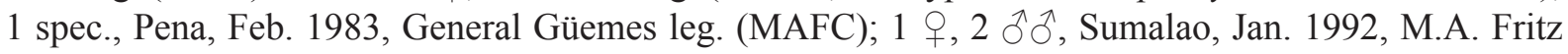

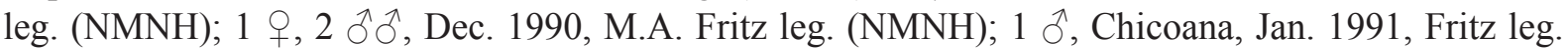

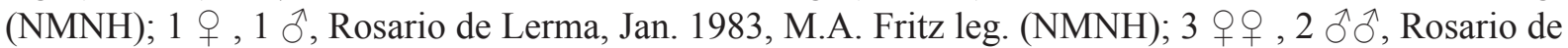
Lerma, 21-23 Dec. 1983, M. Wasbauer leg. (CDFA); 5 spec., Rosario de Lerma, 1983, M.A. Fritz leg.

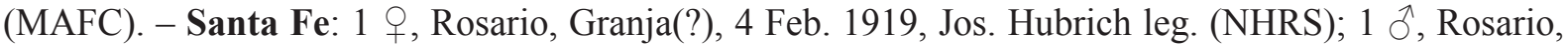
1 Nov. 1912, Jos. Hubrich leg. (NSMT); 1 ô, Rosario, 10 Nov. 1912, Jos. Hubrich leg. (NSMT); 1 q,

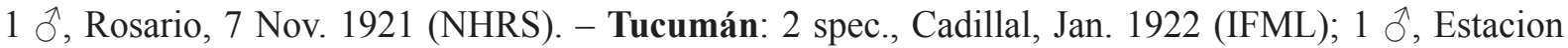
Aráoz, 8 Jan. 1927 (NHRS); 1 spec., Quebrada de Lules, 27 Nov. 1927, L. Stange leg. (IFML); 1 q, same collecting data as preceding but no date (NMNH); 1 +, 11 Oct. 1898, P. Giraud(?) leg. (MNHN); 1 q, 30 Oct. 1898, P. Giraud(?) leg. (MNHN); 1 spec., 16 Nov. 1923, Schreiter leg. (IFML); 1 ठ̊, 9 Nov. 1929, H.A. Jaynes leg. (NMNH); 1 spec., Feb. 1917 (IFML); 1 §̊, G.F. Moznette leg. (NMNH); 1 ㅇ (MNHN).

BOLIVIA: - Dep. Tarija: 1 +, Bermejo, 24 Nov. 1948 (NHRS) [illegible].

BRAZIL: - Mato Grosso: 1 , Rohde leg. (ZMHB; syntype of Pseudopachylosticta leucogaster).

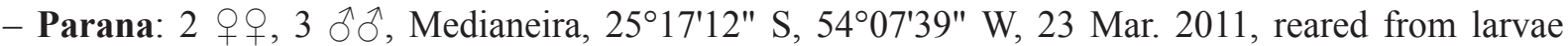
collected on Talinum paniculatum, S. Neser leg. (NMNH). - Piauí: 1 ○ (?) (HNHM; holotype of Amasis brasilensis). - Santa Catarina: 1 + , Penha, 264ㅇ' S, 48³8’ W, 15 Oct. 2007, Neser and Paterson leg. (ZMHB). - Province unknown: 2 우 (ZMHB).

PARAGUAY: - Asunción: 1 + , 18-19 Oct. 1904, [A.] Vezényi leg. (HMNH; holotype of Amasis neotropica). - Cordillera: 1 q, Caacupé, 9 May 2001, Y. Kimura leg. (NSMT); 1 \&, 1 $\lesssim$, San Bernardino,

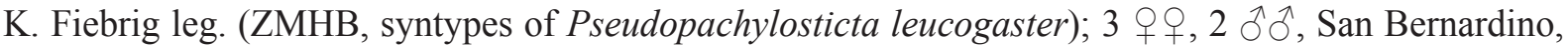
K. Fiebrig leg. (ZMHB); 1 \%, San Bernardino (NHRS) - Caaguazú: 1 spec., Dec. 1977, M.A. Fritz leg. (MAFC). - Concepción: 2 spec., 6 Nov. 1932, 2 Dec. 1933, A. Schulze leg. (MCZ); - Paraguari: 1

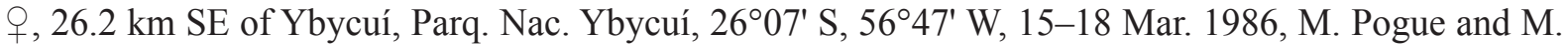
Solis leg. (NMNH). - Guairá: 1 ð̃, Villarica, Sep. 1938 (NHRS); 1 \&, Villarica (NHRS). - Province unknown: 1 (ZMHB; holotype of Pseudopachylosticta leucogaster atroscutella Mallach); 1 , , 1883, P. Jorday leg. (HMNH); 5 q, 1 § (SDEI).

Redescription (female, male structures only mentioned when differing from females)

Measurements. Medium-sized sawflies, body length 9-11 mm.

CoLOR. Females (Fig. 14) predominantly black to dark brown with slight metallic sheen, thorax dorsally reddish orange, extensive creamy-white patch ventrally on anterior part of abdomen; all legs dark brown to blue with metallic sheen. Males (Fig. 15) predominantly black to dark metallic blue, except for small orange areas laterally on pronotum and at wing bases and creamy-white band laterally on abdomen. Wings in both sexes moderately infuscate.

HEAD. Eyes slightly converging ventrally, inner margins slightly incurved. Posterior ocelli at level with dorsal margin of eyes (Fig. 14C). Toruli in middle of face, closer to median ocellus than to ventral margin of clypeus. Epistomal sulcus absent. Clypeus ventral margin evenly curved. Gena medially less wide than width of eye, wider dorsally than ventrally. Malar space very low. Occipital carina absent. Sclerotisation between occipital and oral foramina present. Antennae with five antennomeres (Fig. 14C); antennomere 1 approx. $2 \times$ as long as wide, antennomere 2 approx. as wide as long, antennomere $31.7 \times$ as long as antennomere 4, antennomere 5 distinctly expanded distally. Labrum broad, convex, hairy, raised in the middle, distal margin evenly curved. Mandibles less than $1 / 2$ the height of head, with three 
teeth each, inner margin not serrated. Maxilla with stipes of approx. equal width throughout, palps with four palpomeres, shorter than labial palps. Labial palps with three palpomeres, palps inserting at level with maxillary palps. Postmentum narrow strip, approx. 8-9× as long as wide.

Thorax. Pronotum comparatively high medially, with transverse groove extending from sublaterally on pronotum to posterodorsal corner; lateral groove continuous with transverse, extending ventrally on pronotum until ventral to anterior thoracic spiracle where it terminates; pronotum fused with mesopleuron ventrolaterally of spiracle from halfway between spiracle and ventrolateral corner of pronotum. Dorsal cervical sclerite present. Propectus without lateral projection, propleural sulcus present, medioventral margins of propectus widely separated, posteriorly extended into narrow points. Prosternum laterally extended, separate from katepisterna which do not extend to lateral coxal articulation point. Anterior fore tibial spur straight, simple, not much longer than posterior spur, spurs pointed and sclerotized apically. Mesonotum with distinct median sulcus and deep notauli (Fig. 14B), laterophragmal apodeme short, lobed, postscutellum absent. Small anterodorsal part of mesopleuron separated from rest by vertical groove (Fig. 14A), prepectus absent as separate sclerite. Horizontal carina absent laterally on mesopleuron. Posterior thoracic spiracle visible in lateral view, situated in incurvation in dorsal margin of mesopleuron. Median midcoxal articulations adjacent, only separated by small wedge of cuticle. Mesofurca with mesospina, anterior arms short, lateral arms elongate. Insertion of mesonoto-metanotal muscle on anterior margin of metanotum not on conspicuous structure; cenchri approx. $3 \times$ as broad as long. Anapleural cleft present, small. Metapleuron fused with abdominal tergum 1 along dorsal margin; posteroventral metapleural apodeme absent; paracoxal sulcus curving posteriorly, terminating in the middle of the metapleural sulcus; metacoxal foramina open dorsally, without metapleural inflection laterally. Metafurca with anterior arms inconspicuous, lateral arms elongate. Hind coxa less than twice as long as wide, median carina or spine absent. Hind femoral ventral spur absent. Hind tibial apical spurs shorter than apical width of tibia. Hind basitarsomere $0.8 \times$ tarsomeres $2-4$ (Fig. 14A), tarsal claws bifid, teeth subequal in length.

WINGS. Fore wing with vein $\mathrm{M}$ joining $\mathrm{Sc}+\mathrm{R}$ close to Rs $+\mathrm{M}$; vein $2 \mathrm{r}-\mathrm{m}$ posteriorly inserts on cell $2 \mathrm{M}$, close to anterior end of $2 \mathrm{~m}$-cu (Fig. 14D); vein $1 \mathrm{~m}$-cu oriented obliquely, inserting on Rs $+\mathrm{M}$ some distance from $2 \mathrm{r}-\mathrm{m}$ (distance $1 \mathrm{~m}-\mathrm{cu}-2 \mathrm{r}-\mathrm{m}$ at least $1 / 3$ distance $\mathrm{M}-1 \mathrm{~m}-\mathrm{cu}$ on $\mathrm{Rs}+\mathrm{M}$ ); posterior anal vein present proximally and distally but discontinuous in the middle. Hind wing cell R1 closed; vein M terminates proximally in vein Rs, cells Rs and M separated, cell Rs reduced in size and cell M extending to vein Rs proximally (Figs 14D, 15); cross vein 2a absent.

ABdomen. Tergum 1 not subdivided medially (Fig. 14B), median carina absent, lateral carina absent, posterior margin slightly curved; tergum 1 not brighter colored than other abdominal terga. Metaphragma continuous medially, of approx. equal height throughout, median foramen absent. Lateroterga around abdominal spiracles separated from median terga as demarcated by conspicuous fold. Cerci triangular, length approx. equals width at base. Ovipositor apparatus with $1^{\text {st }}$ valvula having longitudinal line, sawteeth strongly asymmetric, broadened in ventral view, slanted proximally, serrulae absent (Smith 1988: fig. 45); tip of $1^{\text {st }}$ and $2^{\text {nd }}$ valvulae not curving dorsally; ventral margin with tufts of setae along its length, tufts on small lobes.

\section{Comments}

Described by Kirby (1882) as Amasis subflavata from a single male from Cordova (= Córdoba), Argentina. Mallach (1929) established the genus Pseudopachylosticta. Smith (1988) accepted only P. subflavata as valid, placing four additional described species in synonymy.

Pseudopachylosticta subflavata resembles a smaller and less compact Pachylosticta spp. Both genera are predominantly colored blue-black metallic, and the females have extensively reddish-brown coloration 
on the thorax; furthermore, the labrum is raised in the middle, and the maxillary and labial palps are reduced, having four and three palpomeres, respectively. Apart from the size difference, Pachylosticta and Pseudopachylosticta mainly differ in wing characters. The pterostigma is not thickened and protruding in male Pseudopachylosticta, and the fore wing vein $1 \mathrm{~m}-\mathrm{cu}$ inserts on vein Rs $+\mathrm{M}$ more proximally, the distance between $2 \mathrm{r}-\mathrm{m}$ and $1 \mathrm{~m}$-cu insertions on Rs $+\mathrm{M}$ being at least $1 / 3$ of the distance between $\mathrm{M}$ and $1 \mathrm{~m}-\mathrm{cu}$ insertions on Rs+M; in the hind wing, the cell Rs is much smaller than cell $\mathrm{M}$, allowing cell $\mathrm{M}$ to extend to vein Rs proximally. Another difference is that the antennal club, i.e., the $5^{\text {th }}$ antennomere, is more swollen in P. subflavata. Finally, in Pseudopachylosticta the hind basitarsomere is shorter than tarsomeres 2-4 combined, whereas the opposite is the case for Pachylosticta spp.

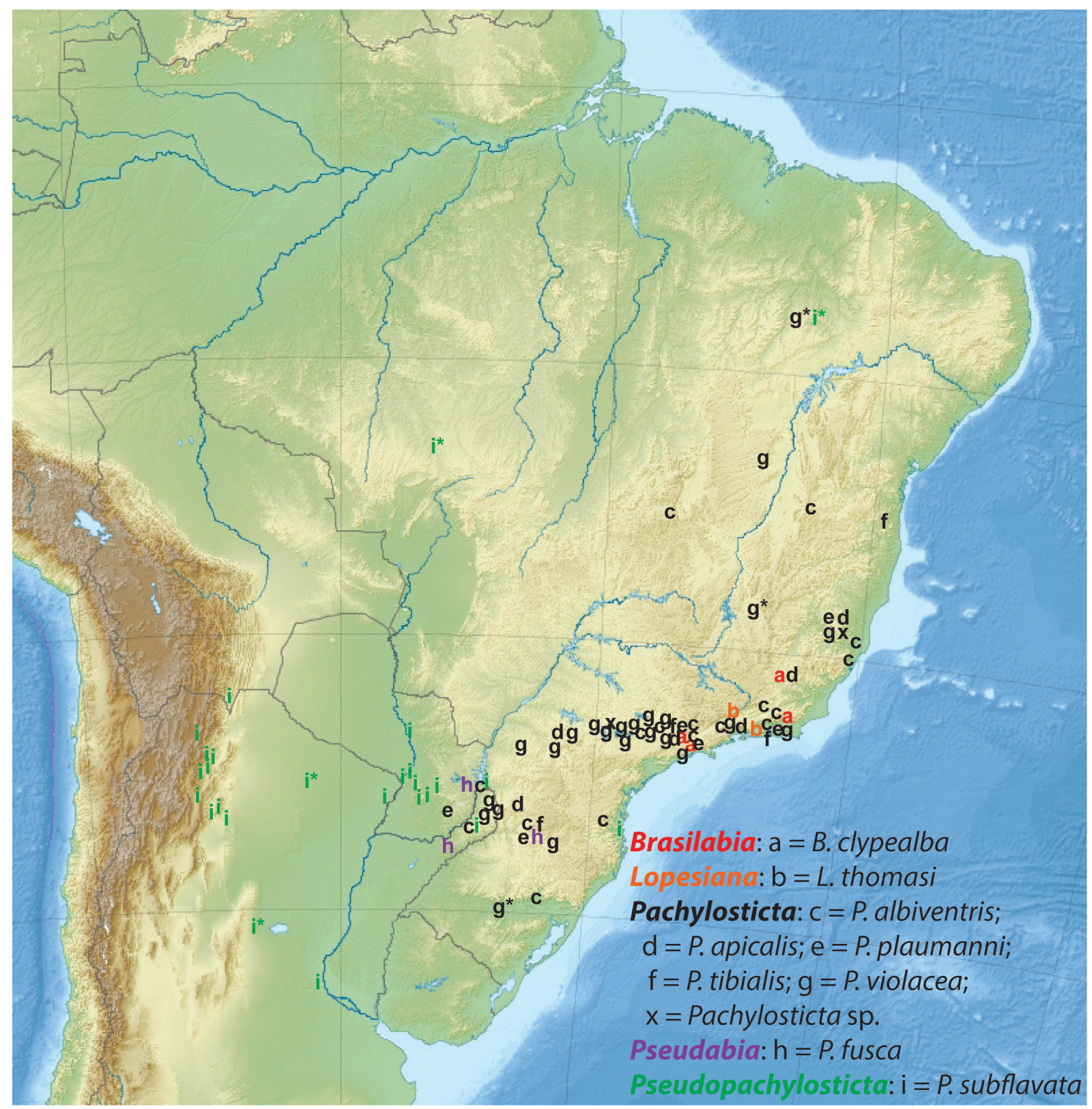

Fig. 16. Distribution of South American Cimbicidae. Records marked with an asterisk are for states within the relevant countries for which no more precise records were available; the markers have been placed approx. in the middle of the state in question. Some records have not been plotted to avoid cluttering the map. 


\section{Discussion}

Vilhelmsen 2018 retrieved Pachylostictinae as monophyletic under most analytical settings, except in implied weights analyses with low K value settings (1-3). When monophyletic, Pachylostictinae was placed as sister to Corynidinae; when not, Lopesiana was placed as sister to all other Cimbicidae, whereas the other genera came out as successive outgroups to Abiinae + Cimbicinae (see Vilhelmsen 2018 for more details on topology and character support). Putative synapomorphies for Pachylostictinae are the metapleuron with the paracoxal sulcus curving posteriorly and terminating in the middle of the metepisternum. The only consistently retrieved sister group relationship within the subfamily is Pachylosticta + Pseudopachylosticta, supported by mouthpart (labrum raised in the middle, reduced maxillary and labial palps) and ovipositor characters $\left(1^{\text {st }}\right.$ valvula teeth strongly asymmetric and without serrulae) as well as the distinctly metallic body color.

It seems that the South American genera form a basal clade or grade within the Cimbicidae. They retain several features probably plesiomorphic for the family (e.g., normal sized mandibles, presence of a dorsal cervical sclerite, presence of a well-developed propleural sulcus and corresponding ridge; Vilhelmsen 2018). The fossil record of Cimbicidae is restricted to the northern hemisphere, the oldest fossil is of $56 \mathrm{Ma}$ and can possibly be associated with the Abiinae + Cimbicinae clade (Vilhelmsen 2018); no fossils have been associated with Pachylostictinae. The phylogenetic position, morphological diversity and geographic isolation of the South American Cimbicidae indicate that they have evolved in isolation from the rest of the family for a considerable time, probably at least since the Tertiary.

Apart from Pachylosticta albiventris, P. violacea and Pseudopachylosticta subflavata, only few records are available for each species of South American Cimbicidae, and they almost never provide any detailed information about the collecting habitat. This makes it very difficult to make inferences about the biology of these wasps and what kind of habitat they occur in. Brasilabia, Lopesiana and Pseudabia have only been collected in comparatively restricted areas, the two former in southeastern Minas Gerais, Rio de Janeiro and eastern São Paulo (all in Brazil), Pseudabia in northeastern Misiones (Argentina), Santa Catarina (Brazil) and southeastern Paraguay (Fig. 16). Most records of Pachylosticta spp. are from northeastern Argentina and southeastern Brazil, with a few outliers in Bahia, Distrito Federal, and Piauí. Pseudopachylosticta has the most aberrant distribution, with little overlap with the other genera. Most records are in northern Argentina and southern Paraguay, extending west to the base of the Andes in Argentina and Bolivia; in addition, there are a few outlying records from Mato Grosso and Piauí (both Brazil). The almost complete separation of the distribution ranges of the putative sister groups Pachylosticta and Pseudopachylosticta is the most striking pattern in the records plotted for the Pachylostictinae.

The distribution of Pachylostictinae falls within an area that is apparently restricted by the Prepuna and Puna ecoprovinces in the Andes to the west, the Caatinga and Cerrado to the north and northwest, the Atlantic Ocean to the east, and the Pampa grasslands to the south (see Morrone 2006). Pseudopachylosticta has a distribution apparently on the fringes of the Chaco Province of the Chacoan subregion, extending into the Monte and perhaps the Yungas ecoprovinces to the west and the Parana subregion to the east. Interestingly, according to Paterson et al. (2014: fig. 2) Pereskia aculeata, one of the two known host plants of Pseudopachylosticta subflavata, only occurs in the easternmost distribution range of the wasp. The two apparent clusters of Pseudopachylosticta records centered in southeastern Paraguay and northwestern Argentina in the Andean foothills, respectively, might be separated by areas where few suitable habitats are available, either because of a different climate or habitat degradation. On a more comprehensive time scale, the Pachylosticta/Pseudopachylosticta split might have been caused by a vicariance event resulting from the advent of the Chacoan subregion in the Tertiary, splitting the formerly continuous Amazonian and Parana forests (Morrone 2006). Alternatively, Pseudopachylosticta might have dispersed from the Parana to the Chacoan subregion after the formation of the latter. 
Disregarding outlying records of Pachylosticta albiventris and P. violacea in Mato Grosso and Piauí, the remaining records of South American Cimbicidae fall within the distribution of the Brazilian Atlantic rainforest, the Parana forest and the Araucaria angustifolia forest provinces, all within the Parana subregion (Morrone 2006). The future prospects of the cimbicids associated with this subregion are probably bleak. The Atlantic rainforest has suffered the longest and one of the most intensive episodes of human induced depredation of all South American biomes during the last 500 years; currently, less than $15 \%$ of the area originally covered by this forest remains (https:/en.wikipedia.org/wiki/Atlantic_Forest). Indeed, many of the older collection localities of Pachylostictinae are situated in what are now suburbs in the sprawling metropolises of Rio de Janeiro and São Paulo.

\section{Acknowledgements}

Agnièle Touret-Alby, Akihito Shinohara, Alexey Solodovnikov, Andreas Taeger, Eliana Buenaventura Ruiz, Felipe Vivallo, Gavin Broad, Gustavo Miranda da Silva, Hege Vårdal, Jane Costa, Michael Ohl, and Suzanne Ryder provided access or helped facilitate access to the material examined. Stephan Blank provided records from CSCA. Gavin Broad and two anonymous reviewers helped improve the manuscript. Mention of trade names or commercial products in this publication is solely for the purpose of providing specific information and does not imply recommendation or endorsement by the USDA. USDA is an equal opportunity provider and employer.

\section{References}

Benson R.B. 1938. On the classification of sawflies (Hymenoptera Symphyta). Transactions of the Royal Entomological Society of London 87: 353-384.

Conde O. 1932. Cimbicinen aus dem Museu Paulista (Hym., Tenthred.). Revista de Entomologia 2 (4): 437-441.

Conde O. 1937. Ergänzungen zu den neotropischen Zaraeini (Hym. Tenthr.). Notulae Entomologicae 17: $14-17$.

Conde O. 1940. Eine Erwiderung auf Herrn R. Malaise Kritik in 'The genus Leptocimbex Sem. and some other Cimbicidae' Entomolgisk Tidskrift 60, Hft. 1-2,1939, pg. 22-26. Entomologisk Tidskrift 61: $26-28$

Evenhuis N.L. 2018. The Insect and Spider Collections of the World Website. Available from http://hbs.bishopmuseum.org/codens/ [accessed 19 Oct. 2018].

Jörgensen P. 1913. Las Tenthredinoidea (Hym.) de la República Argentina. Anales del Museo Nacional de Historia Natural Bernardino Rivadavia 24: 247-288.

Kirby W. 1837. Fauna Boreali-Americana; or the Zoology of the Northern Parts of British America: containing Descriptions of the Objects of Natural History Collected on the late Northern Land Expeditions under Command of Captain Sir John Franklin. By John Richardson, assisted by William Swainson and the reverent William Kirby. Part the Fourth and Last. The Insects. J. Fletcher, Norwich. https://doi.org/10.5962/bhl.title.39293

Kirby W.F. 1882. List of Hymenoptera with descriptions and figures of the typical specimens in the British Museum. 1.Tenthredinidae and Siricidae Vol. 1. Trustees of the British Museum of Natural History, London.

Klug F. 1824. Entomologische Monographieen [sic!]. G. Reimer, Berlin.

Klug F. 1834. Uebersicht der Tenthredinetae der Sammlung. Jahrbücher der Insectenkunde mit besonderer Rücksicht auf die Sammlung des Königl. Museum in Berlin herausgegeben 1: 223-253. 
Konow F.W. 1907. Systematische Zusammenstellung der bisher bekannt gewordenen Chalastogastra (Hym.). Zeitschrift fur Systematische Hymenopteriologie und Dipterologie 1: 177-192, 257-272, $417-$ 432, 481-496.

Latreille P.A., Lepeletier de Saint-Fargeau, A., Serville, A.J.G. \& Guérin-Méneville, F.É. 1828. Entomologie, ou Histoire naturelle des Crustacés, des Arachnides et des Insectes. In: Latreille P.A. (ed.) Encyclopédie méthodique. Histoire naturelle, 1825-1828, Vol. 10(2). Agasse, Paris. https://doi.org/10.5962/bhl.title.82248

Linné C. 1758. Systema Naturae, per regna tria naturae secundum classes, ordines, genera, species cum characteribus, differentiis, synonymis, locis. Editio Decima Reformata. (10th ed.) Vol. 1.: 1-824. Laurentius Salvius, Holmiae. https://doi.org/10.5962/bhl.title.559

Malaise R. 1939. The genus Leptocimbex Sem., and some other Cimbicidae. Entomologisk Tidskrift 60 (1-2): 1-28.

Mallach N. 1929. Neue neotropische Cimbicinen. (Hym. Tenthred.). Deutsche Entomologische Zeitschrift [1929] (4): 285-288.

Mocsáry A. 1909. Chalastogastra nova in collectione Musei nationalis Hungarici. Annales historiconaturales Musei Nationalis Hungarici 7: 1-39

Morrone J.J. 2006. Biogeographic areas and transition zones of Latin America and the Caribbean islands based on panbiogeographic and cladistics analyses of the entomofauna. Annual Review of Entomology 51: 467-494. https://doi.org/10.1146/annurev.ento.50.071803.130447

Paterson I.D., Vitorino, M.D., de Cristo, S.C., Martin, G.D. \& Hill, M.P. 2014. Prioritisation of potential agents for the biological control of the invasive alien weed, Pereskia aculeata (Cactaceae), in South Africa. Biocontrol Science and Technology 24 (4): 407-425. https://doi.org/10.1080/09583157.2013.864382

Perty J.A.M. (1830) Delectus animalium articulatorum, quae in itinere per Brasiliam annis MDCCCXVII - MDCCCXX jussu et auspiciis Maximiliani Josephi I. Bavariae regis augustissimi peracto collegerunt Dr. J. B. de Spix . ... et Dr. C. F. Ph. de Martius. digessit, descripsit, pingenda curavit Dr. Maximilianus Perty, .... Praefatus est et edidit Carol. Frideri. Philip. de Martius. Accedit Dissertatio de insectorum in America meridionali habitantium vitiae genere, moribus et distributione geographica. Monachii, impensis Editoris. 1830-1834. (3 Fasc.). [1-2] + I-III + 1-44 + 1-224. F. Fleischer, Munich / Leipzig.

Rohwer S.A. 1911. The Genotypes of the Sawflies and Woodwasps, or the Superfamily Tenthredinoidea. United States Department of Agriculture, Bureau of Entomology, Technical Series 20: 69-109.

Schrottky C. 1910. Neue südamerikanische Hymenoptera. Entomologische Rundschau 27: 168-169.

Smith D.R. 1988. A synopsis of the sawflies (Hymenoptera: Symphyta) of America south of the United States: introduction, Xyelidae, Pamphiliidae, Cimbicidae, Diprionidae, Xiphydriidae, Siricidae, Orussidae, Cephidae. Systematic Entomology 13: 205-26.

Spinola M. 1840. Hyménopères recuellis a Cayenne en 1839 par M. Leprieur, pharmacien de la marine royale. Annales de la Société entomologique de France 9: 129-204.

Taeger A., Blank, S.M. \& Liston, A.D. 2010. World catalog of Symphyta (Hymenoptera). Zootaxa 2580: $1-1064$.

Vilhelmsen L. 2000. The ovipositor apparatus of basal Hymenoptera (Insecta): phylogenetic implications and functional morphology. Zoologica Scripta 29: 319-345.

Vilhelmsen L. 2015. Morphological phylogenetics of the Tenthredinidae (Insecta: Hymenoptera). Invertebrate Systematics 29: 164-190. https://doi.org/10.1071/IS14056 
Vilhelmsen L. 2018. Giant sawflies and their kin: morphological phylogeny of Cimbicidae. Systematic Entomology [online edition]. https://doi.org/10.1111/syen.12314

Manuscript received: 11 May 2018

Manuscript accepted: 27 August 2018

Published on: 6 December 2018

Topic editor: Gavin Broad

Desk editor: Jeroen Venderickx

Printed versions of all papers are also deposited in the libraries of the institutes that are members of the EJT consortium: Muséum national d'Histoire naturelle, Paris, France; Botanic Garden Meise, Belgium; Royal Museum for Central Africa, Tervuren, Belgium; Natural History Museum, London, United Kingdom; Royal Belgian Institute of Natural Sciences, Brussels, Belgium; Natural History Museum of Denmark, Copenhagen, Denmark; Naturalis Biodiversity Center, Leiden, the Netherlands; Museo Nacional de Ciencias Naturales-CSIC, Madrid, Spain; Real Jardín Botánico de Madrid CSIC, Spain; Zoological Research Museum Alexander Koenig, Bonn, Germany. 